\title{
ilkokul 4. Sınıf Öğrencilerinin Çevre ve Alan Konularında Yaptıkları Hataların Analizi $^{1}$
}

\section{An Analysis of 4th Grade Students' Errors in the Topics of Perimeter and Area}

\author{
Ramazan DiVRIK , Dr., Dumlupınar Bilim ve Sanat Merkezi, Afyonkarahisar/TÜRKIYE, rdivrik42@gmail.com \\ Pusat PILTEN , Doç. Dr., Hoca Ahmet Yesevi Uluslararası Türk-Kazak Üniversitesi, Beşeri Bilimler Fakültesi, \\ Türkistan/KAZAKISTAN, pusatpilten@ayu.edu.kz
}

\begin{abstract}
Divrik, R. ve Pilten, P. (2021). Illkokul 4. sınıf öğrencilerinin çevre ve alan konularında yaptıkları hataların analizi. Batı Anadolu Eğitim Bilimleri Dergisi, 12(1), 333-356.
\end{abstract}

Geliş tarihi: 27.01 .2021

Kabul tarihi: 09.06.2021

Yayımlanma tarihi: 28.06.2021

Öz. Çevre ve alan konuları öğrencilerin ilkokul yıllarında karşılaştığı birbiri ile sürekli karıştırılan iki konu arasında yer almaktadır. Bu yüzden ilkokul yıllarında çevre ve alan konularında öğrencilerin kullandığı çözüm stratejilerinin belirlenmesi; bu çözümlerde yapılan hataların tespit edilerek gereken önlemlerin alınması önemli görülmektedir. İlkokul 4. sınıf düzeyinde çevre ve alan konularında öğrencilerin kullandığı çözüm stratejilerinin belirlenmesi ve yapılan hataların analiz edilmesi bu çalışmanın amacını oluşturmaktadır. Araştırmada nitel araştırma desenlerinden durum çalışması deseni kullanılmıştır. Araştırmanın verileri 174 ilkokul dördüncü sınıf öğrencisinden toplanmış; verilerin analizinde betimsel analiz kullanılmıştır. Analiz safhasında ilk önce öğrencilerin sorulara vermiş oldukları cevapların doğruluk oranları ve soruların çözümünde kullanılan stratejiler belirlenmiştir. Ardından öğrencilerin hatalı cevap kâğıtları üzerinden hata türleri belirlenerek analizler yapılmıştır. Araştırma sonucunda, çevre hesaplama sorularında formül kullanma, zihinden işlem yapma ve kenar uzunluklarını toplama stratejileri; alan hesaplama sorularında birimkareleri sayma, zihinden işlem yapma ve bütün parça ile taralı parça ilişkisini ele alma stratejilerinin kullanıldığı tespit edilmiştir. Çevre hesaplama sorularında en fazla işlem hatası, ne yapacağını bilmeme ve nasıl tanımlayacağını bilmeme hataları yapılmıştır. Alan hesaplama sorularında ise işlem hatası, geometrik şeklin yanlış modellenmesinden kaynaklanan hatalar ve nasıl tanımlayacağını bilmeme hataları yapılmıştır. Öğrencilerin yapmış olduğu bu hataların giderilmesinde, çevre ve alan kavramlarının öğretiminde öncelikle öğrencilerin kavramsal gelişimini destekleyici çalışmalarla derslerin tasarlanması ve öğrencilerin geometrik şekillere ait çevre ve alan formüllerine kendilerinin ulaşması önerilmektedir.

Anahtar Kelimeler: İlkokul, Matematik eğitimi, Çevre, Alan, Strateji, Hata.

\begin{abstract}
The topics of perimeter and area are among the two themes that students learn during their primary school years, and are mostly confused with each other. For this reason, it is deemed important to identify the solution strategies used by students in the themes of perimeter and area during primary school years, to identify the errors they make in these solutions, and to take the necessary measures. Identifying the solution strategies used by students in the topics of perimeter and area at the 4th grade level of primary school and analyzing the errors they make constitute the purpose of this study. The case study method, which is one of the qualitative research methods, was used in this study. The data of the study were collected from 174 primary school fourth grade students, and descriptive analysis was used in the analysis of the data. In the analysis phase, first, the accuracy levels of the answers the students gave to the questions and the strategies they used in solving the questions were identified. Then, the types of errors on the students' incorrect answer sheets were identified and analyses were carried out. As a result of the research, it was found that the strategies of
\end{abstract}

\footnotetext{
${ }^{1}$ Bu çalışma, II. Uluslararası Akademik Araştırmalar Kongresi'nde sunulan sözlü bildirinin genişletilmiş halidir.
} 
using formulas, mental processing, and adding up the length of sides are used in perimeter questions; and the strategies of counting unit squares, mental processing, and using the relation of the shaded region to the entire region were used in the area questions. The most common errors made in perimeter questions were not knowing what to do and not knowing how to define. The errors made in area questions, on the other hand, were calculation errors, incorrect modeling of the geometric shape, and not knowing how to define. To eliminate these errors students make, it is recommended that the lessons be carried out in a way that supports the conceptual development of the students and the students reach the perimeter and area formulas of the geometric shapes themselves in the teaching of the themes of perimeter and area.

Keywords: Primary school, Mathematics ducation, Perimeter, Area, Strategy, Error. 


\section{Extended Abstract}

Introduction. Measurement is a process-based task in terms of obtaining the answer. In this process, it is extremely important to select the property to be measured and to select a unit suitable for this property to be measured (Baykul, 2014; Grant and Kline, 2003; Stephan and Clements, 2003). Measurement is the comparison of a known property of an object with a unit that can be used to measure this property and expressing it numerically (Olkun and Toluk Uçar, 2020). The topics of perimeter and area included in the measurement learning area are not actual measurements, but the properties of geometric shapes to be measured. Therefore, one should be very careful in teaching these concepts, which are both confused with each other and also misperceived as measurement (Baykul, 2014; Chappell and Thompson, 1999; Dağlı and Peker, 2012; Outhred and Mitchelmore, 2000; Tan Şişman and Aksu, 2009). While measuring the perimeter of a shape in perimeter calculation; in area calculation, how many of the regional units there are within the area to be measured should be determined (Çilingir Altıner, 2020; Olkun and Toptaş, 2019). In these subjects, students must first make an intuitive comparison and ordering, then measure with nonstandard and existing units (Ministry of National Education [MEB], 2018). However, after students learn the concept of perimeter, they learn the concept of area and its formulas, so these two concepts are often confused with each other. For this reason, these two concepts should be associated with each other in teaching the topics of perimeter and area, and they should not be taught in a way based on formulas (Güner and Uygun, 2019). Teachers should be very careful in teaching these two topics, which are included in the curriculum from the third grade on in primary schools. In this context, the purpose of this study is to identify the strategies used by primary school fourth grade students in topics of perimeter and area and to analyze the errors they make.

Method. In the study, the case study method, one of the qualitative research methods, was used to analyze the strategies students use and the errors they make in perimeter and area calculations. The case study is a research pattern that reveals understanding, defining, predicting, or controlling an individual, group, or cultural situation (Akar, 2017). The study group of the research consists of 174 fourth-grade students, who were reached with the convenience sampling method. As a data collection tool, 6 open-ended questions were used that include calculating the perimeter of given shapes, creating a shape with a given perimeter, and writing down the course taken while calculating the perimeter of a given shape; calculating the area of given shapes, creating a shape with a given area in unit squares, and writing down the course taken while calculating the area of a given shape. The accuracy levels of the answers the students gave to the questions, the strategies they used in solving the questions, and the errors they made were analyzed with the descriptive analysis method.

Results. Most of the students know that the perimeter can be calculated by adding up the length of sides of the geometric shapes, and the areas of shapes can be calculated by adding up the unit squares that cover the area of the shape. In perimeter questions, the students used the strategies of using formulas, mental processing, and adding up the length of sides; in area questions, counting unit squares, mental processing, and using the relation of the shaded region to the entire region. The errors made in area questions are calculation errors, not knowing what to do, incomplete calculation, incorrect modeling of the geometric shape, inability to conceptualize the geometric shape, error in drawing unit squares, not knowing how to define, and using area formulas instead of perimeter formulas. The errors made in area questions, on the other hand, are calculation errors, not knowing what to do, error in calculating the perimeter, incorrect modeling of the geometric shape, not knowing how to define, and using perimeter formulas.

Discussion and Conclusion. The fact that they figured out to add up the length of sides of geometric shapes to calculate the perimeter and to add up the unit squares that cover the region to calculate the areas of the shapes shows that the teachers carry out lessons in accordance with the curriculum. However, the point that should be considered here is that teachers should not teach based on rote 
learning, where formulas are the focus. Also, the fact that students used different strategies in perimeter and area questions shows that they make choices depending on their own individual pace. This can be considered as diversity. According to the errors made, it was observed that the students acted hastily in calculations to solve the questions quickly. While this situation shows that students have practical shortcomings, it also shows that they cannot fully grasp these two topics. In addition, the students did not know what to do in questions that required creating a geometric shape, a type of question that they are not familiar with from the questions in the textbooks or the lessons; so they confused the themes of perimeter and area with each other. The difficulty students had in verbally expressing a mathematical process shows that they focused on calculations rather than conceptual meaning. In reducing these errors, it is deemed important not to teach the perimeter and area formulas to the students in a way based on rote memorization and to carry out lessons in a way that supports their conceptual learning. 


\section{Giriş}

Matematik, günlük yaşamda herkesin hayatını kolaylaştıran bir araç olmasının yanı sıra aslında bir düşünme şeklidir (Güler Selek, 2020). Bu düşünme şeklinin geliştirilmesinde matematikteki yapılar ve bunlar arasındaki ilişkiler öğrencilere gösterilmeli ve her bir konunun bir önceki konu ile ilişkisine değinilmelidir. Matematikteki yapılar ve bunlar arasındaki benzer ve farklı yönler öğretim programının bütünlüğünü oluşturmaktadır. Bu bütünlüğün sağlanmasında matematiğin gerçek hayatla olan ilişkisi göz ardı edilmemeli; farklı uygulamalar ile bu bağlantıyı öğrencilerin kurmaları sağlanmalıdır (Biber, 2019; Pesen, 2020). Örneğin, ikinci sınıf seviyesindeki öğrenciler toplama ve çıkarma işlemleri arasındaki ilişkiyi kavramada $3+2=5$ işleminin $5-3=2$ işlemi ile ilişkisini kurabilmelidir. Karenin, küpün; dikdörtgenin, dikdörtgenler prizmasının; dairenin, silindirin ve üçgenin, piramidin birer bileşeni olduğunu görebilmelidir. Bunun yanı sıra matematikteki yapılar arasında bir ön şart ilişkisi de bulunmaktadır. Çok katlı bir binanın birinci katına çıkılmadan ikinci katına çıkılamayacağı gibi alt düzey matematiksel kavramlar öğrenilmeden üst düzey kavramlar da öğrenilememektedir. Burada öğretmenlere düşen görev öğrencilerin gerçek dünya ile bağlarını koparmadan bu ön şart ilişkisini görmelerini sağlamak olmalıdır (Pesen, 2020).

Ölçme, çocukların günlük hayatta sıklıkla karşılaştıkları bir durumdur. Örneğin, çocukların oyun esnasında kumaşın veya telin uzunluğunu ölçmesi; defter veya kitabını kaplaması; kantinden alış veriş yapması; bir kekin pişme süresini takip etmesi; sinemaya gittiğinde bilet alması; sevdiği programların saatini beklemesi; meyve suyu içmek için bunu bir kaba boşaltması veya doktora gittiğinde tartılması, boyunun ve ateşinin ölçülmesi gibi birçok durumda çocuklar ölçmeyle karşılaşmaktadır (Çilingir Altıner, 2019). Bunun yanı sıra matematikte sayılar, istatistik ve geometri konularıyla da ölçme yakından ilişkilidir (Zembat, 2009). Bu nedenle ölçmenin gerekliliği ve bu kavramın öğrencilere sezdirilmesi önemlidir (Güner ve Uygun, 2019). Ölçme, bir nesnenin bilinen bir özelliğinin bu özelliği ölçmede kullanılabilecek bir birim ile karşılaştırılması ve sayısal olarak ifade edilmesidir (Olkun ve Toluk Uçar, 2020). "Bir kalemin uzunluğu gibi bir nesnenin niteliğine sayısal bir değer atanması" işidir (National Council of Teachers of Mathematics [NCTM], 2000).

Türkiye'de 4. sınıf öğrencilerinin katıldığı uluslararası düzeyde yapılan TIMSS sınavı; sayılar, ölçme ve geometri, veri öğrenme alanlarından oluşmaktadır. Ölçme ve geometri öğrenme alanı içerisinde ölçmeye ayrılan oran \%15'tir. Ölçmeye ayrılan bu oran içerisinde öğrencilerden uzunluğu ölçmek için cetveli kullanabilme; uzunluk, kütle ve zaman içeren problemleri çözebilme; basit çokgenlerin çevresini ve alanını hesaplayabilme ve hacimleri belirlemek için küpleri kullanabilme becerileri beklenmektedir (Millî Eğitim Bakanlığı [MEB], 2020). Dolayısıyla ölçmenin uluslararası düzeyde yapılan bir sınavda önemli bir orana sahip olması ve öğrencilerin bu becerilerinin değerlendirilmeye alınması ölçme konusunun önemini göstermektedir.

Günlük hayatımızın her aşamasında kullanılan ölçme, önemi sebebiyle ilkokul matematik dersi öğretim programında da ağılıklı olarak yer almaktadır (MEB, 2018). Ölçme, sonucun elde edilişi yönünden süreç temelli bir iştir. Bu süreçte ölçülecek özelliğin ve ölçülecek bu özelliğe uygun bir birimin seçilmesi son derece önemlidir. Neyin ölçüldüğü ve ölçmenin ne anlama geldiği anlaşılmazsa elde edilen sonucun yorumlanması da mümkün olamaz (Baykul, 2014; Grant ve Kline, 2003; Stephan ve Clements, 2003). Nesnenin boyutu, hacmi, alanı veya ağırlığı ölçülecek özellik olarak belirlenebilir (Curry, Mitchelmore ve Outhred, 2006). Bu özelliklerin ölçülmesinde de santimetre, metre, metrekare, gram, kilogram, litre gibi standart birimler kullanılabileceği gibi karış, kulaç, adım, kap gibi standart olmayan birimler de kullanılabilir (Barrett vd., 2011; Olkun ve Toluk Uçar, 2020). 
Ölçmede öncelikle bir nesnenin ölçülecek niteliğinin belirlenmesi için önce bunun farkına varılması beklenir. Bu da bireyin doğumdan itibaren çevresinde gördüğü, duyduğu ölçme ile ilgili kavramları kullanmasıyla başlar (Çilingir Altıner, 2019). İlkokula gelindiğinde ise küçük-büyük, uzakyakın, ağır-hafif, uzun-kısa, geniş-dar gibi karşılaştırma ve sıralama etkinlikleriyle ölçme etkinliklerine başlanır. Daha sonra ölçülecek nesnenin standart olmayan birimlerle ölçülmesiyle etkinliklere devam edilir. Bu etkinliklerde örneğin, "Sınıfımızın boyu kaç adımdır?, "Sıramızın uzunluğu kaç karıştır?" gibi sorularla öğrencilerin elde ettiği sonuçları karşılaştırarak standart bir birime gereksinim duyulacağını görmeleri sağlanır. Standart birimler ile ölçmeye geçildiğinde ise ölçme amacına göre birimlerin seçilmesi ve bu birimler arasındaki geçişlerin gösterimleri öğrenciler tarafından yapılır. Somut metre kullanılarak "Bir metre kaç santimetre veya desimetredir?" gibi sorular ile alt birimlerle üst birimlerin ilişkisini öğrencilerin keşfetmeleri sağlanır (Curry vd., 2006; Olkun ve Toluk Uçar, 2020). Elde edilen bu bilgilerin problem çözme, yaklaşık tahminde bulunma ve yorumlama süreçlerinde uygulanmasıyla öğrencilerin günlük yaşam durumlarına ölçme becerilerini transfer etmeleri beklenmektedir (Çilingir Altıner, 2019). illkokul matematik dersi öğretim programında ölçme öğrenme alanında öğrencilerin önce sezgiye dayalı karşılaştırmalar yapması ve elde edilen sonuçların sıralanması beklenmektedir. Sonrasında standart olmayan ve standart olan birimlerle öğrencilerin ölçümler yapması hedeflenmiştir (MEB, 2018). Programda ölçme öğrenme alanı, paralarımız, tartma, uzunluk ölçme, zaman ölçme, sıvı ölçme, çevre ölçme ve alan ölçme alt öğrenme alanlarından oluşmaktadır (Divrik, 2020). Çevre ve alan aslında geometrik şekillerin ölçülecek özellikleridir; birer ölçme değildir. Ancak ölçme öğrenme alanı içinde yer almaktadır (Baykul, 2014). Dolayısıyla hem kendi içinde çok karıştırılan çevre ve alan konuları hem de birer ölçme olarak algılanan bu kavramların öğretiminde çok dikkatli olunmalıdır. Çünkü bu iki kavram birbiriyle sürekli karıştırılmaktadır (Chappell ve Thompson, 1999; Dağlı ve Peker, 2012; Outhred ve Mitchelmore, 2000; Tan Şişman ve Aksu, 2009).

Çevre, düzlem üzerindeki bir şekli sınırlayan çizgidir. Alan, bir nesnenin bir bölgedeki kapladığı yerin iki boyutlu ölçüsüdür (Çilingir Altıner, 2020; Olkun ve Toptaş, 2019). Çevre hesaplamada bir şeklin etrafındaki uzunluk ölçülürken alan hesaplamada, ölçülecek alan içinde belirlenen bölgesel ölçüden kaç tane olduğu belirlenir. Alan ölçümünü "kenarlar içinde kalan bölüm" olarak ifade eden öğrencilerin tespit edildiği araştırma sonuçlarına göre alan ve alan hesaplama kavramları birbirine karıştırılmaktadır (Gürefe, 2018). Çevre ölçmede ilk olarak standart olmayan birimlerle öğrencilere bir bölge etrafındaki mesafeyi ip veya ölçüm bandı ile ölçme fırsatı verilmelidir. Daha sonra çevreyi bulmak için bölgenin çeşitli taraflarının uzunluklarını bulabilecekleri etkinlikler yaptırılmalıdır (Çilingir Altıner, 2020). Ölçme aracı ile çevre kavramı öğrenildikten sonra her defasında ölçüm yapmak zor olacağından şeklin etrafındaki birim uzunluk sayısını sayma yöntemiyle çevre bulmaya geçilebilir. Bu sayede öğrenciler farklı şekillerin çevrelerinin aynı olabileceğini de görmüş olurlar (Güner ve Uygun, 2019). Kareler ile şeklin kaplanması alan ölçümünde sıkça başvurulan bir yoldur. Kaplama ile alan kavramı pekiştirildikten sonra her defasında kaplama yapmak zor olacağından birimkare sayma yöntemiyle alan bulmaya geçilebilir. Ancak yapılan bir çalışmada öğrencilerin birimkareyi alan birimi olarak görmediği belirlenmiştir (Olkun, Çelebi, Fidan, Engin ve Gökgün, 2014). Alan hesaplamaya geçmeden önce öğrencilerin standart olmayan ve olan birimlerle geometrik şekillerin iç bölgelerinde ölçümler yapmalarına fırsat tanınmalıdır. Böylece, alan ölçmede de standart birimlerin gerekliliği öğrenciler tarafından görülebilir (Güner ve Uygun, 2019).

Illkokul matematik dersi öğretim programı çevre ölçme alt öğrenme alanında, 3. sınıf öğrencilerinden verilen nesnelerin çevrelerinin belirlenmesi; şekillerin çevre uzunluklarının önce standart olmayan birimlerle sonra standart birimlerle ölçülmesi beklenmektedir. Ayrıca öğrenilen bu becerilerin kullanıldığı problemlerin çözülmesi istenmektedir. 4. sınıf öğrencilerinden kare ve dikdörtgenin çevre uzunluklarının belirlenerek bu uzunlukların belirlenmesinde kenar uzunluklarının nasıl ele alındığını açıklamaları istenmektedir. Aynı çevre uzunluğuna sahip farklı geometrik şekilleri öğrencilerin çizmeleri ve bu uzunlukların ele alındığı problemlerin çözülmesi hedeflenmektedir. Alan ölçme alt öğrenme alanında, 3. sınıf öğrencilerinden standart olmayan birimler ile şekillerin 
kaplanması istenerek alan kavramı fark ettirilmeye çalışıır. Ayrıca bu alanın standart olmayan birimlerle tahmin edilmesi ve doğruluğunu öğrencilerin kontrol etmesi istenmektedir. 4. sınıf öğrencilerinden birimkare kavramının fark edilmesine yönelik çalışmalar yapmaları, kare ve dikdörtgenin alanı hesaplanırken toplama ve çarpma işlemlerinin nasıl ele alındığını açıklamaları beklenmektedir (MEB, 2018).

Öğrenciler çevre kavramından sonra alan kavramıyla ve formülleriyle karşılaştıklarında bu iki kavram genellikle birbiriyle karıştııılmaktadır. Bu nedenle, çevrenin şeklin kenar uzunluklarının toplamı olduğu, alanın şeklin kenarlarının içinde kalan bölge olduğu ve çevre değişirken alanın değişmek zorunda olmadığı anlatılmalıdır (Güner ve Uygun, 2019). Bu bağlamda birbiri ile karıştırılan çevre ve alan konularıyla ilgili çeşitli araştırmalar yapılmışır. Bu araştırmalarda çevre ve alan konularının öğretiminde etkili olabilecek yöntemler, materyaller ve stratejiler belirlenmiştir (Bozoğlu, 2013; Güner ve Uygun, 2019; Gürefe, 2018; Hacıömeroğlu ve Apaydın, 2009; Kültür, Kaplan ve Kaplan, 2002; Yıldırım Yakar ve Albayrak, 2018). Bu çalışmaların yanı sıra bu iki konunun öğretiminde karşılaşılan güçlükleri ortaya koyan çalışmalar yapılmıştır. Bu çalışmalarda, çevre ve alan konularında öğrencilerin kavram yanılgılarına sahip oldukları (Dağlı ve Peker, 2012; Outhred ve Mitchelmore, 2000; Tan Şişman ve Aksu, 2009; 2015); öğrencilerin çevre/alan formüllerini etkin biçimde kullanmada sıkıntılar yaşadıkları (Dağlı ve Peker, 2012; Tan Şişman ve Aksu, 2009; 2015); öğretmen adaylarının çevre ve alan konularındaki pedagojik alan bilgilerinin yetersiz olduğu (Runnalls ve Hong, 2017; Şimşek ve Boz, 2015); öğretmenlerin alan öğretiminde uzunluk x genişlik formülünü kullanma eğiliminde oldukları ve öğrencilerin bu formülü ezberlemek zorunda kaldıkları belirlenmiştir (Kidman ve Cooper, 1997; Olkun vd., 2014; Stephan ve Clements, 2003; Zacharos, 2006). Bu güçlüklerin ortaya çıkmasında da öğrencilerin çevre ve alan konularında kavramsal yaklaşıma değil de formüllere dayalı uygulamalara daha fazla maruz kalmaları gösterilmektedir (Zacharos, 2006).

Görüldüğü üzere çevre ve alan konularında çok farklı ve sayıda araştırma yapılmıştır. Bu araştırmalarda çevre ve alan konularının öğretiminde bu iki kavramın birbirleriyle ilişkilendirilmesi ve formüllerinin doğrudan öğrencilere verilmemesi gerektiği belirtilmiştir (Güner ve Uygun, 2019). Dolayısıyla ilkokul üçüncü sınıftan itibaren öğretmenler çevre ve alan konularının öğretiminde önemli hususları gözden kaçırmamalı ve öğrencilerin yapabileceği hatalar konusunda daha dikkatli olmalıdırlar. Çevre ve alan konularının zorluğu gereği bu konularda yapılabilecek hataların belirlenerek bunların giderilmesine yönelik önlemlerin alınması ve öğretmenlerin öğretimlerinde bunlara dikkat etmesi önemli görülmektedir. Bu doğrultuda ilkokul dördüncü sınıf seviyesinde öğrencilerin çevre ve alan konularında kullandıkları stratejilerin belirlenerek, yaptıkları hataların analizinin yapılması bu çalışmanın amacını oluşturmaktadır. Bu amaçla aşağıdaki sorulara cevap aranmıştır:

1. İlkokul 4. sınıf öğrencilerinin çevre hesaplama sorularına verdikleri cevapların doğruluk oranları nedir?

2. İlkokul 4. sınıf öğrencilerinin verilen bir şeklin çevresini hesaplarken kullandıkları stratejiler nelerdir?

3. İlkokul 4. sınıf öğrencilerinin çevre hesaplama sorularında yaptıkları hata türleri nelerdir?

4. Illkokul 4. sınıf öğrencilerinin alan hesaplama sorularına verdikleri cevapların doğruluk oranları nedir?

5. İlkokul 4. sınıf öğrencilerinin verilen bir şeklin alanını hesaplarken kullandıkları stratejiler nelerdir?

6. İlkokul 4. sınıf öğrencilerinin alan hesaplama sorularında yaptıkları hata türleri nelerdir? 


\section{Yöntem}

\section{Araştırmanın Modeli}

$\mathrm{Bu}$ araştırmada öğrencilerin çevre ve alan hesaplamalarında kullandıkları stratejiler ve yaptıkları hatalar analiz edilmiştir. Bu amaçla çalışmada nitel araştırma desenlerinden biri olan durum çalışması deseni kullanılmıştır. Durum çalışması bir birey, grup veya kültür durumunu anlamaya, tanımlamaya, tahmin etmeye veya kontrol etmeye çalışan bir araştırma desenidir (Akar, 2017; Yıldırım ve Şimşek, 2006). Örnek olay çalışması olarak da bilinen durum çalışmaları, zaman ve mekân bağlamında bir varlığın tanımlandığı ve özelleştirildiği araştırmalardır. Bu araştırmalarda ele alınan varlık alan içinde yer alan bir okul olabileceği gibi alanlar arasını kapsayan çok sayıda okul da olabilir (Büyüköztürk, Kılıç Çakmak, Akgün, Karadeniz ve Demirel, 2020).

Durum çalışmaları araştırmacılar tarafından çalışılan durum ve amaçları bakımından farklı şekillerde sınıflandırılmaktadır. Bu araştırmada iç içe geçmiş çoklu durum deseni kullanılmıştır. İç içe geçmiş çoklu durum deseninin kullanıldığı çalışmalarda birden fazla durum incelenmekte ve bu durumların birden fazla analiz birimleri bulunmaktadır (Yin, 2014). Bu araştırmada çevre ve alan konuları incelenecek durumları; bu durumlar içerisinde öğrencilerin ortaya koyduğu çözüm stratejileri ve yapılan hatalar analiz birimleri olarak belirlenmiştir. Bu kapsamda öncelikle veri toplama aracında yer alan çevre ve alan sorularıyla iki farklı duruma ait veriler toplanmıştır. Birinci durumu içeren çevre hesaplama soruları ilk olarak kullanılan stratejiler ardından yapılan hatalar bağlamında analiz birimi olarak ele alınmıştır. İkinci durumu içeren alan hesaplama soruları da çevre hesaplama sorularında olduğu gibi kullanılan stratejiler ve yapılan hatalar bağlamında analiz edilmiştir.

\section{Çalışma Grubu}

Araştırmanın çalışma grubunu, kolay ulaşılabilir örnekleme yöntemiyle belirlenmiş 174 dördüncü sınıf öğrencisi oluşturmaktadır. Belirlenen öğrenciler 2015-2016 eğitim öğretim yılında Afyonkarahisar ili İscehisar ilçesine bağlı devlet okullarında öğrenim görmektedir. Kolay ulaşılabilir örnekleme yöntemi araştırmacılara hız, pratiklik ve ekonomiklik kazandırdığı için tercih edilmektedir (Yıldırım ve Şimşek, 2006). Araştırmacılar bu ilçedeki ilkokullarda öğrenim gören ulaşabildikleri dördüncü sınıf öğrencilerinden verileri toplamıştır.

Dördüncü sınıf, ilkokul öğrencilerinin okullarında son yılı olması nedeniyle, çevre ve alan hesaplama konularının öğretim programının öngördüğü şekilde öğrenildiği son sınıf düzeyidir ve hazırlanan veri toplama aracındaki sorular da bu sınıf düzeyindeki öğrencilerin çözebileceği kazanımları kapsamaktadır. Dolayısıyla bu öğrencilerin ortaokula geçmeden önce kullandıkları stratejilerin ve yaptıkları hataların öğretmenler tarafından bilinmesi önemli görülmektedir. illkokulun son yılında öğretmenlerin bu duruma yönelik önlemler alması öğrencilerin ortaokula geçtiklerinde bu sorunları yaşamamalarını sağlayacaktır. Bu nedenle araştırmanın çalışma grubu olarak ilkokul dördüncü sınıf öğrencileri seçilmiştir.

\section{Veri Toplama Aracı}

Bu çalışmada, verilen şekillerin çevresini hesaplama, çevre uzunluğu verilen bir şekil çizme ve verilen bir şeklin çevresi hesaplanırken izlenilen yolu yazma; verilen şekillerin alanını hesaplama, alanı birimkare cinsinden verilen bir şekil çizme ve verilen bir şeklin alanı hesaplanırken izlenilen yolu yazma boyutlarını içeren 6 tane açık uçlu soru kullanılmıştır. Hazırlanan veri toplama aracında bulunan soruların ölçme amacına uygun olup olmadığı ve ölçülmek istenen alanı temsil edip etmediğini belirlemek amacıyla uzman görüşüne başvurulmuştur. Bunun için 4. sınıfları okutan iki 
sınıf öğretmeninin görüşü alınmış; belirlenen soruların ölçme amacına uygun olup olmadığı tartışılarak veri toplama aracına son şekli verilmiştir. Veri toplama aracında yer alan sorular ve sorulara ait bilgiler aşağıda yer almaktadır (Şekil 1).

SORU 1: Aşağıdaki şekillerin çevrelerini hesaplayınız.

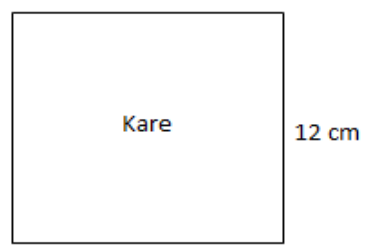

$12 \mathrm{~cm}$

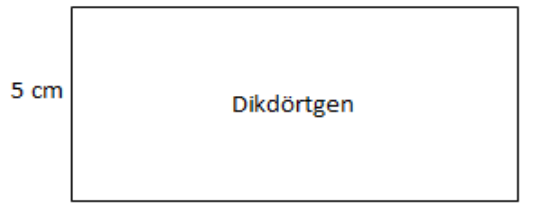

$14 \mathrm{~cm}$

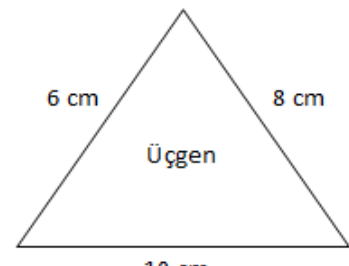

$10 \mathrm{~cm}$

SORU 2: Çevresi $36 \mathrm{~cm}$ olan bir şekil çiziniz.

SORU 3: Verilen bir şeklin çevresini hesaplarken izlediğiniz yolu yazınız.

SORU 4: Aşağıdaki şekillerin alanlarını hesaplayınız.
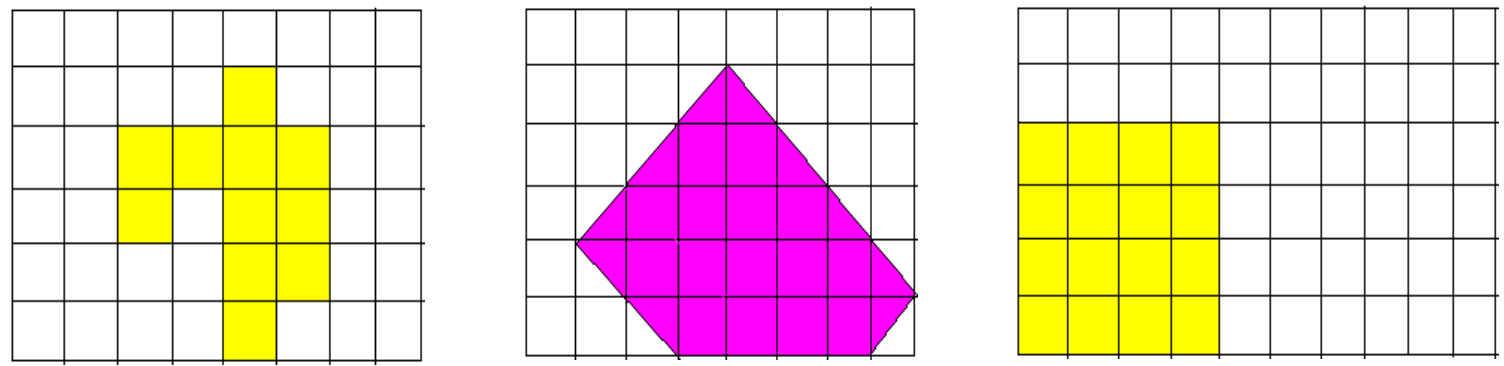

SORU 5: Alanı 27 birimkare olan bir şekil çiziniz.

SORU 6: Verilen bir şeklin alanını hesaplarken izlediğiniz yolu yazınız.

Şekil 1. Veri toplama aracında yer alan sorular

Veri toplama aracında yer alan sorular ilkokul matematik dersi öğretim programında yer alan 4. sınıf kazanımları dikkate alınarak hazırlanmıştır. Bu kazanımlar;

"Kare ve dikdörtgenin çevre uzunlukları ile kenar uzunlukları arasındaki ilişkiyi açıklar."

"Aynı çevre uzunluğuna sahip farkı geometrik şekiller oluşturur."

"Şekillerin alanlarının, bu alanı kaplayan birimkarelerin sayısı olduğunu belirler."

"Kare ve dikdörtgenin alanını toplama ve çarpma işlemleri ile ilişkilendirir."

Belirlenen kazanımları kapsayacak şekilde; 1 . soru ile verilen şekillerin çevresi hesaplanırken kenar uzunluklarını dikkate alma ve işlemsel beceriler ortaya koyma; 2 . soru ile çevre uzunluğu belli olan farklı şekiller oluşturma; 4. soru ile şekillerin alanlarının hesaplanmasında birimkareleri kullanma ve işlemsel beceriler ortaya koyma; 5 . soru ile alanı birimkare cinsinden belli olan şekiller oluşturma; 3. ve 6. sorular ile kavramsal öğrenmeyi sağlama becerileri tespit edilmeye çalışılmıştır. 
Veri toplama aracında yer alan sorulara ilişkin görüşü alınan iki sınıf öğretmeni de hazırlanan sorulara benzer soruların ders kitaplarında yer aldığını ve bu soruların öğrencilerin çözebileceği düzeyde sorular olduğunu belirtmişlerdir. Ancak veri toplama aracında yer alan 3 ve 6 . soruların öğrencilerin çevre ve alan hesaplama sorularına verdikleri yanıtları araştırmadan ziyade onların bu çözüme ilişkin sözel ifade etme becerilerini belirlemeye yönelik sorular olduklarını söylemişlerdir. Bu değerlendirmelere göre, araştırmacılar öğrencilerin çevre ve alan hesaplama konularını gerçekten kavrayıp kavramadıklarını öğrenebilmek adına bu soruların veri toplama aracında kalmasına karar vermişlerdir.

\section{Veri Toplama Aracının Uygulanması}

Durum çalışmalarında veri toplama yöntemi olarak katılımcı gözlem, katılımcı olmayan gözlem, görüşme, doküman incelemesi ve arşiv kayıtları gibi bir dizi nitel veri toplama yöntemi; problemin doğasına göre tek başına veya birlikte kullanılabilir (Yıldırım ve Şimşek, 2006). Bu araştırmada araştırmacılar tarafından hazırlanmış olan 6 tane açık uçlu sorudan oluşan veri toplama aracı öğrencilere uygulanmıştır. Veri toplama aracında yer alan soru sayısı göz önünde bulundurulduğunda pilot bir uygulama gerçekleştirilerek bu veri toplama aracının uygulanmasında bir ders saatinin yeterli olduğuna karar verilmiştir. Daha sonra birinci araştırmacı kolaylıkla ulaşabileceği öğretmenlerle iletişime geçerek hazırlanan veri toplama aracını öğretmenlerin kendi sınıflarında bir ders saatinde uygulamalarını istemiş; uygulama bittikten sonra veri toplama araçlarını öğretmenlerin okullarına giderek toplamıştır. Araştırmacıların beklentilerini karşılayacak düzeyde sayıya ulaşıldığında ise veri toplama işi tamamlanmıştır. Öğrencilerden toplanan bu veriler dokümanlar olarak belirlenmiş ve analiz edilmiştir. Çok sayıda dokümanın analiz edilmesiyle ulaşılmaya çalışılan kavramsal bakış açısına ulaşıldığı için veri toplamak amacıyla başka bir yöntem kullanılmamıştır.

\section{Verilerin Analizi}

Araştırma verilerinin çözümlenmesinde betimsel analiz kullanılmıştır. Araştırma sorusuna ilişkin kavramsal yapının önceden açık biçimde ortaya konulması betimsel analiz yönteminin seçilmesini etkileyen temel unsurdur. Betimsel analiz, bir çerçeve (tema) oluşturma, çerçeveye göre verilerin işlenmesi, bulguların tanımlanması ve bulguların yorumlanması olmak üzere dört aşamadan oluşur (Yıldırım ve Şimşek, 2006). Betimsel analiz yapılırken önce iki araştırmacı tarafından öğrencilerin sorulara verdikleri cevapların doğruluk oranları ve soru çözümlerinde kullanılan stratejiler belirlenmiştir. Ardından öğrencilerin sorulara verdikleri yanlış cevaplar üzerinden yapılan hatalar analiz edilmiştir. Her işlem basamağında öğrenciler tarafından verilen cevaplar frekans çözümlemesine tabi tutulmuştur.

Verilerin analizinde ilk olarak araştırmacılar tarafından hazırlanan bir cevap anahtarıyla öğrencilerin sorulara verdikleri doğru ve yanlış cevaplar belirlenmiştir. İkinci adımda öğrencilerin doğru cevapları üzerinden çözüm stratejilerinin neler olduğu kazanımlar referans alınarak birinci araştırmacı tarafından belirlenmiş ve bir çerçeve oluşturmuştur. Bu çerçeve görüşü alınan bir sınıf öğretmenine sunularak incelemesi istenmiştir. Belirlenen çerçeve doğrultusunda diğer araştırmacı ile birlikte veriler ayrı ayrı kodlanarak kodlayıcı güvenirliği hesaplanmıştır. Güvenirlik yüzdesi Miles ve Huberman'nın (1994) Güvenirlik=Görüş Birliği/(Görüş Birliği+Görüş Ayrılığı)X100 formülü kullanılarak hesaplanmış ve uyum yüzdesi \%91 bulunmuştur. Elde edilen temalar bulgular bölümünde açıklanmış ve temaları en iyi açıklayan öğrenci cevaplarına yer verilmiştir.

Çevre hesaplama sorusunda kullanılan çözüm stratejilerinin belirlenmesinde "formül kullanma" ve "kenar uzunluklarını toplama" stratejileri "Kare ve dikdörtgenin çevre uzunlukları ile kenar uzunlukları arasındaki ilişkiyi açıklar." kazanımı, "Zihinden işlem yapma" stratejisi "Zihinden toplama işlemi yapar." kazanımı referans alınarak kodlanmıştır (MEB, 2018). Ayrıca ders kitabında 
kullanılabilecek çözüm stratejileri şu şekilde açıklanmaktadır: Karenin çevre uzunluğu bulunurken; 1. Karenin dört kenarının uzunluklarını toplama, 2. Çevre uzunluğu=4x(bir kenar uzunluğu). Dikdörtgenin çevre uzunluğu bulunurken; 1 . Dikdörtgenin dört kenarının uzunluklarını toplama, 2. Dikdörtgenin birer uzun ve kısa kenar uzunluğunun toplamını 2 ile çarpma. Alan hesaplama sorusunda kullanılan stratejilerin belirlenmesinde "birimkareleri sayma" ve "bütün parça ile taralı parça ilişkisini ele alma" stratejileri "Şekillerin alanlarının, bu alanı kaplayan birimkarelerin sayısı olduğunu belirler." ve "Kare ve dikdörtgenin alanını toplama ve çarpma işlemleri ile ilişkilendirir." kazanımları, "zihinden işlem yapma" stratejisi "Zihinden çıkarma işlemi yapar." kazanımı referans alınarak kodlanmıştır. Ayrıca ders kitabında kullanılabilecek çözüm stratejileri şu şekilde yer almaktadır: Kare ya da dikdörtgenin alanı bulunurken aşağıdaki yollar izlenebilir; 1 . Birimkareleri sayma, 2. Tekrarlı toplama işlemi yapma, 3. Çarpma işlemi yapma (Özçelik, 2018).

Yapılan hataların belirlenmesinde ise yine birinci araştırmacı belirlenen kazanımlar doğrultusunda öğrencilerin yanlış cevap kâğıtlarını okuyarak bir çerçeve oluşturmuştur. Bu çerçevenin oluşturulmasında öğrencilerin düştükleri hatalar belirlenmiş ve görüşü alınan bir sınıf öğretmeni bu hataların sınıf içi uygulamalarda gerçekten karşılaşılan hatalar olup olmadığı konusunda görüş bildirmiştir. Daha sonra diğer araştırmacı ile birlikte sınıf öğretmeninin görüşü de göz önünde bulundurularak bazı temaların birleştirilmesine karar verilmiştir. Ardından her iki araştırmacı verileri ayrı ayrı kodlayarak kodlayıcı güvenirliği Miles ve Huberman'nın (1994) Güvenirlik=Görüş Birliği/(Görüş Birliği+Görüş Ayrılı̆ıı)X100 formülü kullanılarak hesaplanmış ve uyum yüzdesi \%84 olarak belirlenmiştir. Elde edilen temalar bulgular bölümünde açıklanmış ve temalar öğrenci cevaplarıly desteklenmiştir.

Çevre hesaplama sorularında öğrencilerin yaptıkları "işlem hatası" "Zihinden toplama ve çarpma işlemi yapar." kazanımı; "eksik işlem hatası", "geometrik şeklin kavramsal olarak edinilememesinden kaynaklanan hatalar", "ne yapacağını bilmeme hatası" ve "nasıl tanımlayacağını bilmeme hatası" "Kare ve dikdörtgenin çevre uzunlukları ile kenar uzunlukları arasındaki ilişkiyi açıklar." kazanımı; "geometrik şeklin yanlış modellenmesinden kaynaklanan hatalar" "Aynı çevre uzunluğuna sahip farklı geometrik şekiller oluşturur." kazanımı; "Çevre yerine alan formülü kullanma/işlemi yapma hatası" ve "Birimkareler çizme hatası" "Kare ve dikdörtgenin çevre uzunlukları ile kenar uzunlukları arasındaki ilişkiyi açıklar." ve "Şekillerin alanlarının, bu alanı kaplayan birimkarelerin sayısı olduğunu belirler." kazanımları referans alınarak kodlanmıştır (MEB, 2018).

Alan hesaplama sorularında öğrencilerin yaptıkları "işlem hatası" "Zihinden toplama ve çarpma işlemi yapar." kazanımı; "geometrik şeklin yanlış modellenmesinden kaynaklanan hatalar" "Şekillerin alanlarının, bu alanı kaplayan birimkarelerin sayısı olduğunu belirler." kazanımı; "ne yapacağını bilmeme" ve "nasıl tanımlayacağını bilmeme" hataları "Şekillerin alanlarının, bu alanı kaplayan birimkarelerin sayısı olduğunu belirler." ve "Kare ve dikdörtgenin alanını toplama ve çarpma işlemleri ile ilişkilendirir." kazanımları; "çevre uzunluğunu hesaplama" ve "çevre formülü kullanma" hataları "Şekillerin alanlarının, bu alanı kaplayan birimkarelerin sayısı olduğunu belirler." ve "Kare ve dikdörtgenin çevre uzunlukları ile kenar uzunlukları arasındaki ilişkiyi açıklar." kazanımları referans alınarak kodlanmıştır (MEB, 2018).

\section{Geçerlilik ve Güvenilirlik}

Durum çalışmalarında çoğu kişi araştırmacının öznel yargılarının işe karıştığına inanır. Bu görüşü ortadan kaldırmak için toplanan verilere ait bir kanıt zincirinin oluşturulması ve veri toplama sürecinde kendisinden veri toplanan kişiden görüş alınması gerekmektedir (Yıldırım ve Şimşek, 2006). Çalışmanın yapı geçerliliğinin sağlanmasında öncelikle bir kod şeması geliştirilerek örnek kodlamalar araştırmacılar tarafından yapılmıştır. Ardından öğrencilerin ortaya koyduğu çözüm stratejileri ve hata türleri görüşü alınan sınıf öğretmeninden birine verilerek kontrolü sağlanmıştır. 
İ̧ geçerlilik bir araştırmada yapılan çıkarımlar ve bu çıkarımların ne derece geçerli olduğu ile ilgilidir (Yıldııım ve Şimşek, 2006). İç geçerliliğinin sağlanmasında araştırmacılar ulaştığı stratejilere ve hata türlerine nasıl ulaştıklarını açık bir şekilde anlatmışlar ve bu stratejilere ve hata türlerine örnekler sunmuşlardır. Bu sayede çalışmayı okuyan kişilerin örnek kâğıtlarda çözüm stratejilerini ve hata türlerini görmeleri sağlanmıştır. Ulaşılan bu stratejiler ve hata türleri öğretim programında yer alan kazanımlar ve ders kitaplarındaki konuların açıklamaları dikkate alınarak belirlenmiştir. Bu stratejiler ve hata türleri belirlendikten sonra da görüşü alınan bir sınıf öğretmeninden temaları kontrol etmesi istenmiş ve soruların çözümünde öğrencilerin kullandıkları stratejilerin ve yaptıkları hataların gerçekten sınıf ortamında yapılıp yapılmadığı teyit edilmiştir.

Dış geçerliliği sağlamak için durum çalışmalarında; anket çalışmalarında olduğu gibi "istatistiksel genelleme" yapmak yerine "analitik genelleme" yapmak hedef alınır. Analitik genellemede araştırmacılar, bir evrene genellemeyi değil kavramsal bir model önermeyi düşünürler (Yıldırım ve Şimşek, 2006). Bu çalışmada da çalışılan durumlar ile bir evrene genelleme yapmak amaç edinilmemiş kavramsal bir bakış açısı ortaya koyulmaya çalışılmıştır. Bu kavramsal bakış açısı çevre ve alan konularında öğrencilerin kullandıkları stratejiler ve yaptıkları hatalardır.

Güvenilirlik yapılmış olan bir çalışmanın tekrar edildiğinde aynı veya benzer sonuçlar vermesidir. Bunun için araştırmacılara bağı hata veya yanlıık payının azami ölçüde kontrol edilmesi gerekir (Yıldırım ve Şimşek, 2006). Bu çalışmada da veri toplama ve veri analiz süreci açık bir şekilde açıklanmıştır. Öncelikle öğrencilerden elde edilen kâğıtlar araştırmacılar tarafından tek tek okunarak doğru ve yanlış cevap kâğıtları belirlenmiştir. Daha sonra çevre hesaplama sorularına öğrencilerin verdikleri cevaplar üzerinden çözüm stratejileri ve hata türleri ardından alan hesaplama sorularında öğrencilerin kullandıkları çözüm stratejileri ve hata türleri analiz edilmiştir. Kullanılan çözüm stratejilerinin ve yapılan hata türlerinin neler olduğunu gösterebilmek için de kodlamada kullanılan örneklere yer verilmiştir.

\section{Bulgular}

Bu bölümde öğrencilerin sorulara vermiş oldukları cevapların doğruluk oranları belirlenmiş; ardından hesaplamalarda kullanılan strateji türleri ve yapılan hatalar analiz edilmiştir.

ilkkokul 4. Sınıf Öğrencilerinin Çevre Hesaplama Sorularına Verdikleri Cevapların Doğruluk Oranları Nedir?

Öğrencilerin çevre hesaplama sorularına vermiş oldukları cevapların doğruluk oranları Tablo 1'de gösterilmiştir.

Tablo 1.

Öğrencilerin çevre hesaplama sorularına vermiş oldukları cevapların doğruluk oranları

\begin{tabular}{lrrrrrr}
\hline \multirow{2}{*}{ Yanıt } & \multicolumn{1}{c}{ 1. Soru } & & 2. Soru & & 3. Soru \\
\cline { 2 - 7 } & $f$ & $\%$ & $f$ & $\%$ & $f$ & $\%$ \\
Doğru & 143 & 82.18 & 123 & 70.69 & 132 & 75.86 \\
Yanlış & 31 & 17.82 & 51 & 29.31 & 42 & 24.14 \\
\hline
\end{tabular}

Tablo 1 incelendiğinde, çevre hesaplama sorusuna 143 öğrenci (\%82.18), şekil çizme sorusuna 123 öğrenci (\%70.69) ve çevre hesaplanırken izlenilen yolu yazma sorusuna 132 öğrenci (\%75.86) doğru cevap vermiştir. 1. soruda 31 öğrenci (\%17.82), 2. soruda 51 öğrenci (\%29.31) ve 3. soruda 42 öğrenci (\%24.14) soruyu yanlış cevaplamıştır. Her üç soruda da öğrencilerin büyük bir çoğunluğunun çevre hesaplama konularında gerekli olan çevre uzunlukları ile kenar uzunlukları arasındaki ilişkiyi 
kavradıkları anlaşılmaktadır. Ancak bu soruları yanlış cevaplayan öğrenciler de bulunmaktadır. Özellikle öğrencilerin hesaplama yapabildikleri ancak bir görevi yerine getirirken gerekli olan işlem basamaklarının yazılmasının istendiği 2 ve 3 . sorularda daha fazla zorlandıkları görülmektedir. Buradan hareketle öncelikle öğrencilerin 1. sorunun çözümünde kullandıkları stratejiler belirlenmiş ardından yapılan hatalar tespit edilmiştir.

illkokul 4. Sınıf Öğrencilerinin Verilen Bir Şeklin Çevresini Hesaplarken Kullandıkları Stratejiler Nelerdir? sunulmuştur.

Öğrencilerin 1. sorunun çözümünde kullandıkları stratejilere ait bilgiler Tablo 2'de

Tablo 2.

Öğrencilerin 1. soruda kullandıkları çözüm stratejileri ve örnekleri

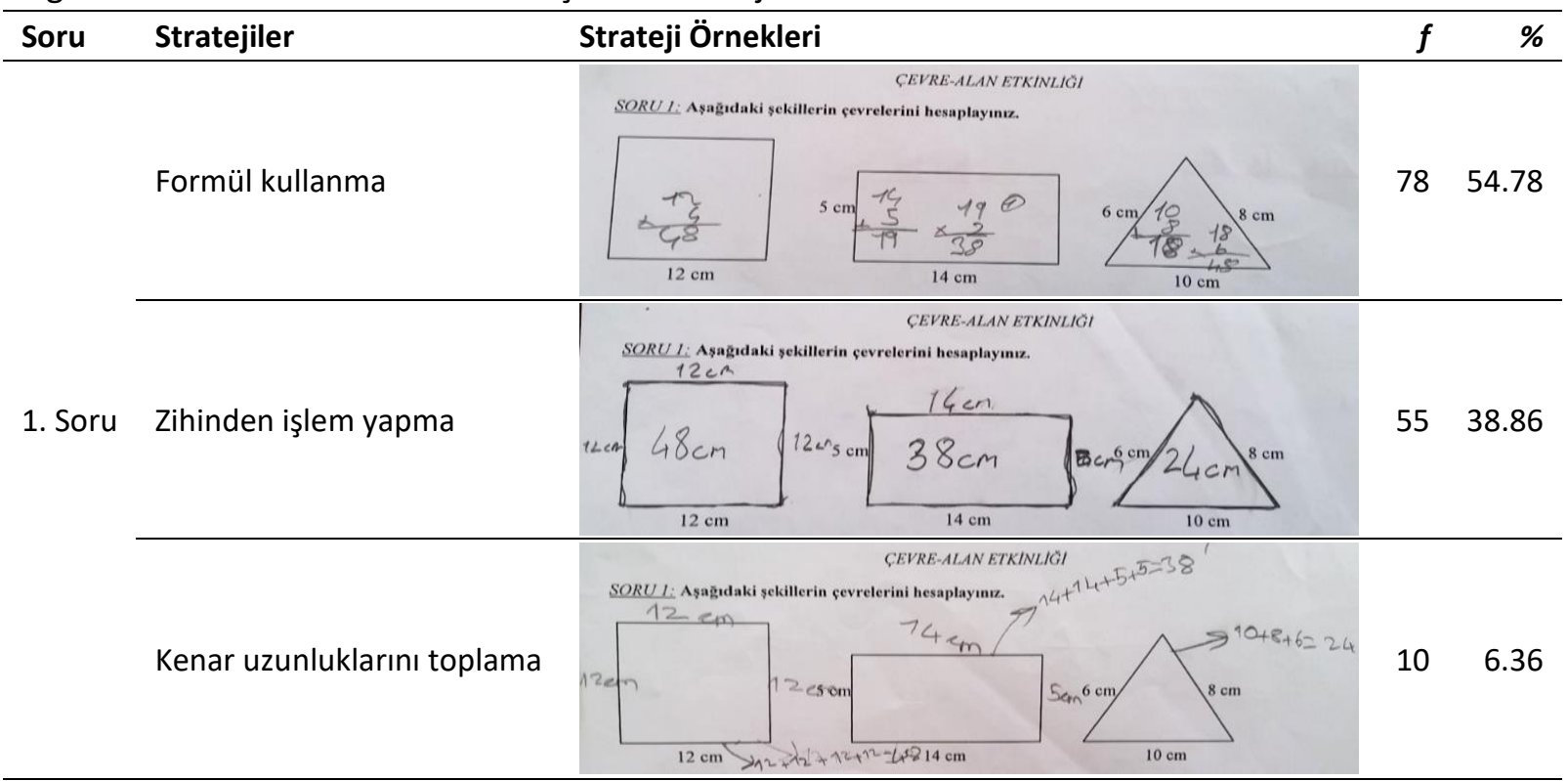

Tablo 2'ye göre, verilen şekillerin çevre uzunluklarının belirlenmesinde 78 öğrencinin (\%54.78) formül kullanma stratejisine, 55 öğrencinin (\%38.86) zihinden işlem yapma stratejisine ve 10 öğrencinin (\%6.36) kenar uzunluklarını toplama stratejisine başvurduğu tespit edilmiştir. Farklı geometrik şekillerin çevre uzunluklarının belirlenmesinde bu şekillerin özelliğine ve öğrencilerin işlem tercihine göre farklı stratejiler kullanılmıştır. Buradan hareketle kare ve dikdörtgenin çevre uzunluklarının hesaplanmasında öğrenciler en fazla bu geometrik şekillerin özelliklerinden dolayı formül kullanarak (kare için, kenar uzunluğu×4; dikdörtgen için, [uzun kenar+kısa kenar]×2) kısa yoldan çevre uzunluklarını hesaplama yolunu tercih etmişlerdir. Ardından bir grup öğrenci geometrik şekillerin kenar uzunluklarını zihinden toplayarak işlem yapmıştır. Son olarak da çevre uzunluğu hesaplama konusunda dikkat edilmesi gereken şeklin bütün kenar uzunluklarını belirleme ve toplama anlamına gelen kenar uzunluklarını toplama stratejisi öğrenciler tarafından tercih edilmiştir.

\section{illkokul 4. Sınıf Öğrencilerinin Çevre Hesaplama Sorularında Yaptıkları Hata Türleri Nelerdir?} sunulmuştur.

Öğrencilerin yanlış cevapladıkları sorularda yaptıkları hata türlerine ait bilgiler ise Tablo 3'te 
Tablo 3.

Öğrencilerin çevre hesaplama sorularında yaptıkları hata türleri ve örnekleri

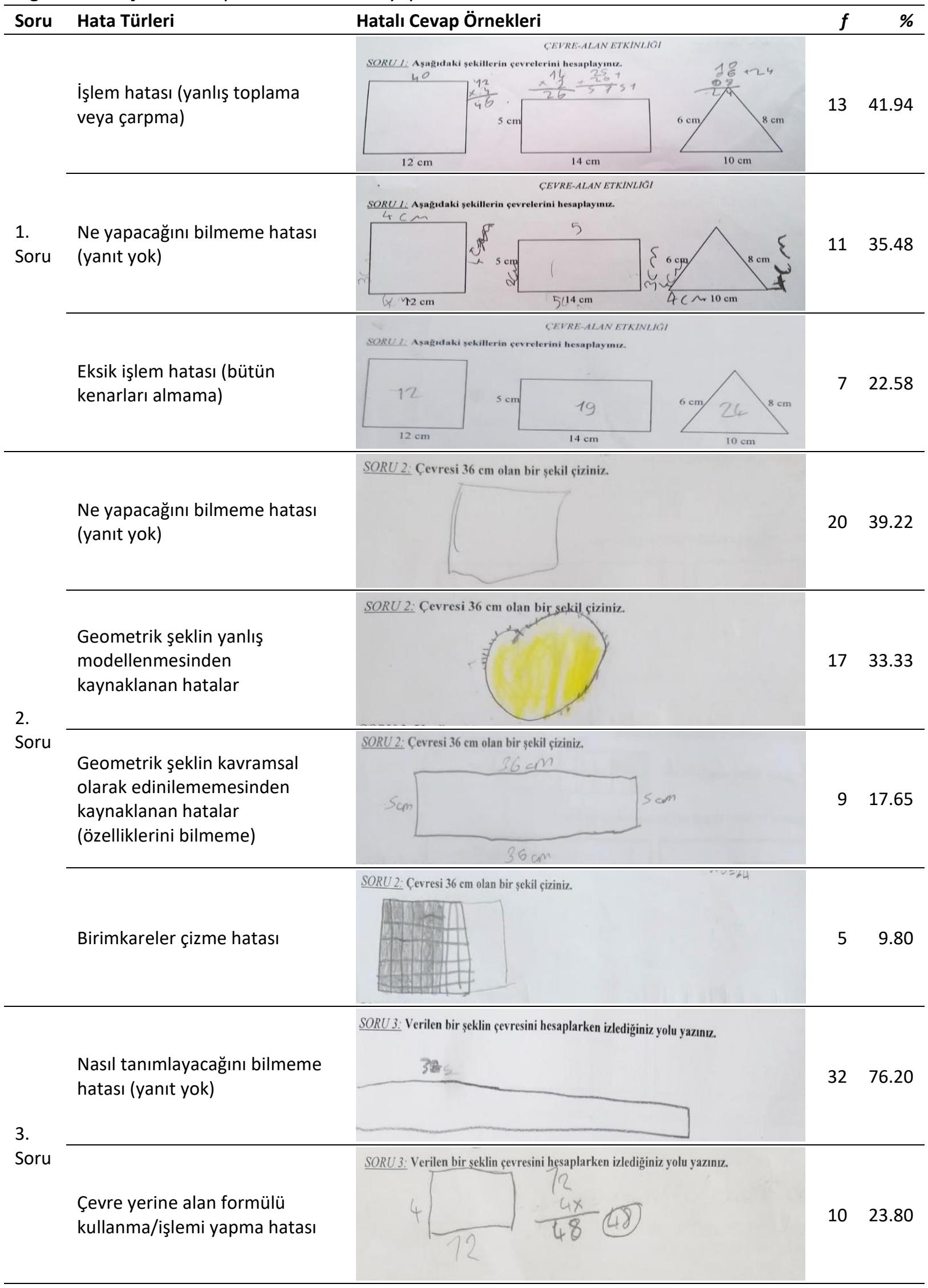


Tablo 3'e göre, 1. soruda öğrenciler tarafından en fazla yapılan hata 13 öğrencinin (\%41.94) yaptığı işlem hatası (yanlış toplama veya çarpma), daha sonra geometrik şekillerin çevrelerinin nasıl hesaplanacağı konusunda herhangi bir bilgisi olmayan 11 öğrencinin (\%35.48) yaptığı ne yapacağını bilmeme hatasıdır (yanıt yok). En az tekrarlanan hata ise yine öğrencilerin geometrik şekillerin çevrelerinin hesaplanmasında bütün kenarlarının işleme dâhil edilmesi gerektiği konusunda eksik bilgiye sahip olmalarından kaynaklı 7 öğrencinin (\%22.58) tekrarladığı eksik işlem (bütün kenarları almama) hatasıdır. Bu verilere göre, verilen bir geometrik şeklin çevre uzunluğunun hesaplanmasında öğrencilerin dikkatsiz davrandıkları ve şekillerin özelliklerini (kare, dikdörtgen) tam olarak bilmedikleri anlaşılmaktadır.

2. soruda sırasıyla 20 öğrenci (\%39.22) ne yapacağını bilmeme hatasını (yanıt yok), 17 öğrenci (\%33.33) geometrik şeklin yanlış modellenmesinden kaynaklanan hataları, 9 öğrenci (\%17.65) geometrik şeklin kavramsal olarak edinilememesinden kaynaklanan hataları (özelliklerini bilmeme) ve 5 öğrenci (\%9.80) birimkareler çizme hatasını tekrarlamıştır. Bu verilere göre, öğrencilerin geometrik şekillerin özellikleri bağlamında yeterli kavramsal bilgiye sahip olmadıkları için doğru modeller çizemedikleri, geometrik şekillerin özelliklerini doğru ortaya koyamadıkları ve alan konusuyla çevre hesaplama konusunu karıştırdıkları görülmektedir.

3. soruda 32 öğrenci (\%76.20) nasıl tanımlayacağını bilmeme hatasını (yanıt yok), 10 öğrenci (\%23.80) çevre yerine alan formülü kullanma/işlemi yapma hatasını yapmıştır. Bu soruda öğrencilerin çevre hesaplama konusunda yeterli bilgiye sahip olmadıkları için izlenilen yolu yazmada yetersiz oldukları ve alan hesaplama konusuyla çevre hesaplama konusunu karıştırdıkları belirlenmiştir.

\section{illkokul 4. Sınıf Öğrencilerinin Alan Hesaplama Sorularına Verdikleri Cevapların Doğruluk Oranları Nedir?}

Öğrencilerin alan hesaplama sorularına vermiş oldukları cevapların doğruluk oranları Tablo 4 'te gösterilmiştir.

Tablo 4.

Öğrencilerin alan hesaplama sorularına vermiş oldukları cevapların doğruluk oranları

\begin{tabular}{|c|c|c|c|c|c|c|}
\hline \multirow{2}{*}{ Yanit } & \multicolumn{2}{|r|}{ 4. Soru } & \multicolumn{2}{|r|}{ 5. Soru } & \multicolumn{2}{|c|}{ 6. Soru } \\
\hline & $f$ & $\%$ & $f$ & $\%$ & $f$ & $\%$ \\
\hline Doğru & 119 & 68.40 & 151 & 86.78 & 123 & 70.69 \\
\hline Yanlış & 55 & 31.60 & 23 & 13.22 & 51 & 29.31 \\
\hline
\end{tabular}

Tablo 4 incelendiğinde, alan hesaplama sorusuna 119 öğrenci (\%68.40), alanı belli olan bir şekil çizme sorusuna 151 öğrenci (\%86.78) ve alan hesaplanırken izlenilen yolu yazma sorusuna 123 öğrenci (\%70.69) doğru cevap vermiştir. 4. soruda 55 öğrenci (31.60), 5. soruda 23 öğrenci (\%13.22) ve 6. soruda 51 öğrenci (\%29.31) soruyu yanlış cevaplamıştır. Her üç soruda da öğrencilerin büyük bir kısmının alan hesaplama sorularında gerekli olan şekillerin alanlarının bu alanı kaplayan birimkarelerden oluştuğu kazanımını edindikleri anlaşımaktadır. Ancak öğrenciler alan hesaplama ve izlenilen yolu yazma sorularında birimkaresi verilen bir şekil çizme sorusuna göre daha fazla zorlanmışlardır. Bunun sebebi olarak öğrencilerin 4. soruda birimkareleri dikkatli sayamamaları, 6. soruda ise tanımlamayı doğru bir şekilde yapamamaları gösterilebilir. 


\section{illkokul 4. Sınıf Öğrencilerinin Verilen Bir Şeklin Alanını Hesaplarken Kullandıkları Stratejiler Nelerdir?}

Öğrencilerin yaptıkları hataların analizine geçmeden önce öğrencilerin 4. soruda kullandıkları stratejilere ait bilgiler Tablo 5'te sunulmuştur.

Tablo 5.

Öğrencilerin 4. soruda kullandıkları çözüm stratejileri ve örnekleri

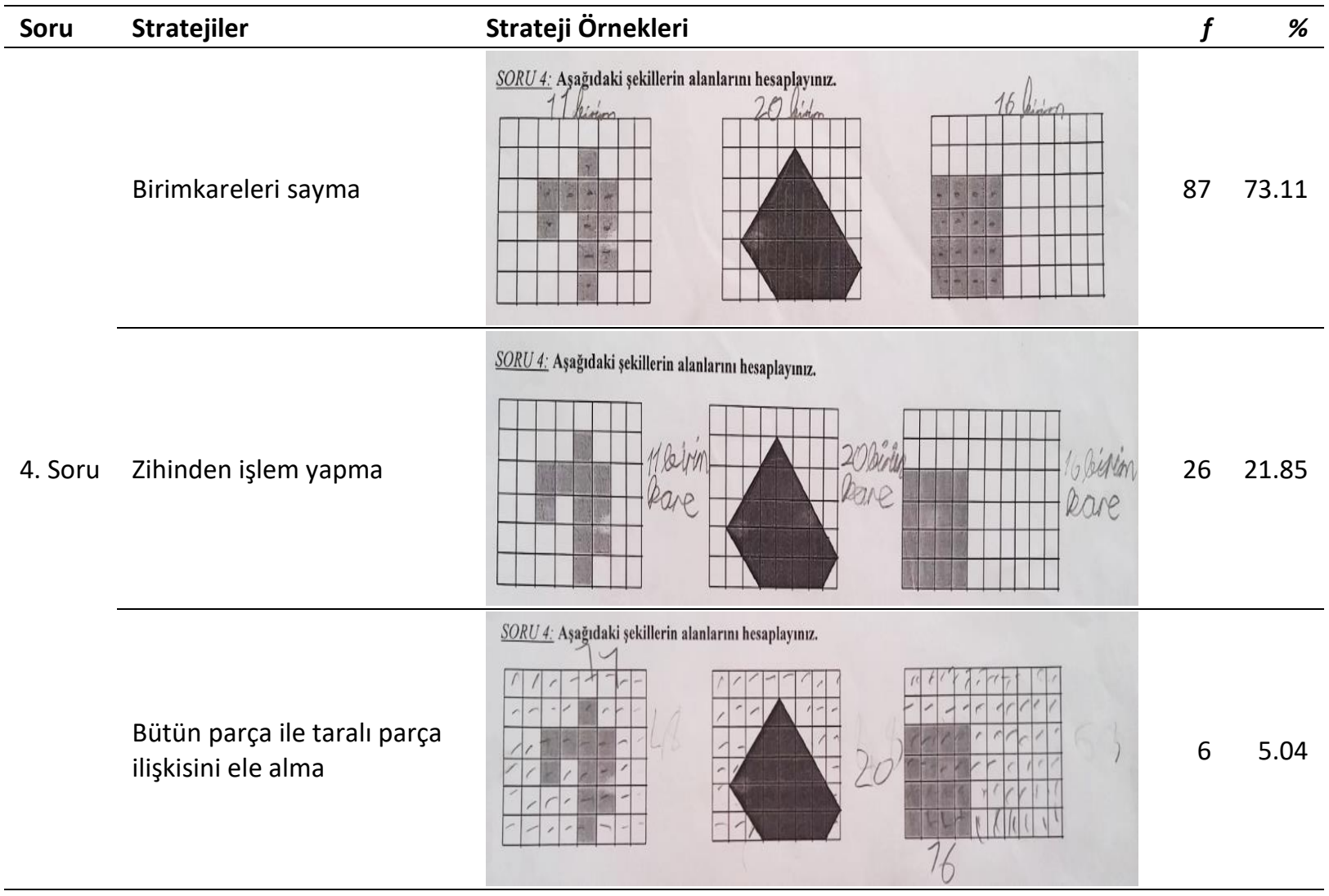

Tablo 5'e göre, verilen şekillerin alanlarının hesaplanmasında 87 öğrenci (\%73.11) birimkareleri sayma stratejisini, 26 öğrenci (\%21.85) zihinden işlem yapma stratejisini ve 6 öğrenci (\%5.04) bütün parça ile taralı parça ilişkisini ele alma stratejisini kullanmıştır. Farklı birimkarelerden oluşan şekillerin alanlarının hesaplanmasında geometrik şekillerin biçimine ve işlem önceliğine göre öğrencilerin farklı stratejileri tercih ettikleri görülmektedir. Bu doğrultuda öğrencilerin büyük bir çoğunluğu emin adımlarla ilerleyerek birimkareleri tek tek sayarak sonucu bulmuştur. Bir kısım öğrenci direkt zihinden hesaplama yaparak sonuca ulaşmış, çok az sayıda bir grup öğrenci de yine emin olmak adına bütün birimkareler ile taralı olan kareler arasındaki ilişkiyi inceleyerek sonuca ulaşmıştır.

\section{illkokul 4. Sınıf Öğrencilerinin Alan Hesaplama Sorularında Yaptıkları Hata Türleri Nelerdir?} sunulmuştur.

Öğrencilerin yanlış cevapladıkları sorularda yaptıkları hata türlerine ait bilgiler ise Tablo 6 'da 
Tablo 6.

Öğrencilerin alan hesaplama sorularında yaptıkları hata türleri ve örnekleri

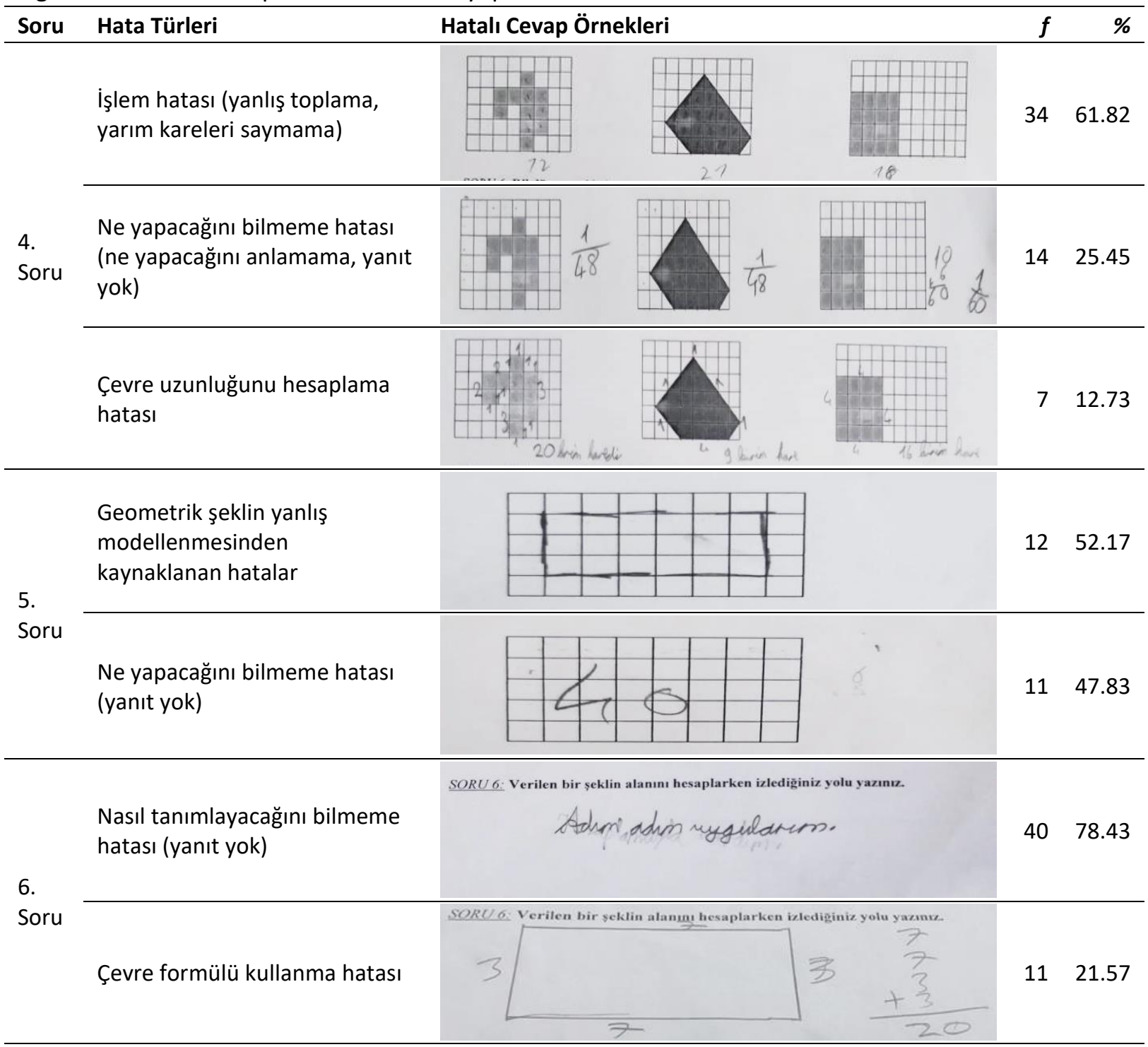

Tablo 6'ya göre, 4. soruda öğrenciler tarafından en fazla yapılan hata 34 öğrencinin (\%61.82) yaptığı işlem hatası (yanlış toplama, yarım kareleri saymama), daha sonra alan hesaplama konusunda herhangi bir bilgisi olmayan 14 öğrencinin (\%25.45) yaptığı ne yapacağını bilmeme hatasıdır (ne yapacağını anlamama, yanıt yok). En az tekrarlanan hata ise 7 öğrencinin (\%12.73) çevre hesaplama yanılgııına düşerek yaptıkları çevre uzunluğunu hesaplama hatasıdır. Bu verilere göre, birimkare cinsinden verilen bir şeklin alanının hesaplanmasında öğrencilerin dikkatsiz davrandıkları ve çevre hesaplama konusuyla alan hesaplama konusunu karıştırdıkları anlaşılmaktadır.

5. soruda 12 öğrenci (\%52.17) geometrik şeklin yanlış modellenmesinden kaynaklanan hataları, 11 öğrenci (\%47.83) ne yapacağını bilmeme hatasını (yanıt yok) tekrarlamıştır. Bu verilere göre, öğrencilerin şekillerin alanlarının birimkarelerden oluştuğu konusunda yeterli kavramsal bilgiye sahip olmadıkları için doğru modellemeler yapamadıkları görülmektedir.

6. soruda 40 öğrenci (\%78.43) nasıl tanımlayacağını bilmeme hatasını (yanıt yok), 11 öğrenci (\%21.57) çevre formülü kullanma hatasını yapmıştır. Bu soruda öğrencilerin alan hesaplama konusunda gereken bilgiye sahip olmadıkları için izlenilen yolu yazamadıkları ve alan hesaplama yöntemiyle çevre hesaplama yöntemini karıştırdıkları belirlenmiştir. 


\section{Tartışma, Sonuç ve Öneriler}

Çevre uzunluğunu hesaplama, çevre uzunluğu belli olan bir şekil çizme ve çevre hesaplama yöntemini açıklama sorularında öğrencilerin büyük çoğunluğunun geometrik şekillerin kenar uzunluklarının toplanmasıyla çevre uzunluğuna ulaşılabileceği bilgisine sahip olduğu sonucuna ulaşılmıştır. Dağlı ve Peker (2012) beşinci sınıf öğrencilerinin en az \%90'ının kenar uzunlukları verilen geometrik şekillerin çevre uzunluğunu hesaplayabildiğini; Tan Şişman ve Aksu (2009) yedinci sınıf öğrencilerinin büyük bir çoğunluğunun (\%76.1) çerçeve yapmak için çevre uzunluğunun bulunması gerektiğini bildiklerini ve yine öğrencilerin büyük bir kısmının (\%83.6) karenin çevresini doğru hesaplayabildiğini tespit etmiş olmaları bu çalışmanın sonuçları ile paralellik göstermektedir. 3. sınıfta nesnelerin çevrelerinin standart olmayan ve olan birimlerle ölçülmesi, 4. sınıfta kare ve dikdörtgenin çevre uzunluğunun hesaplanmasında kenar uzunluklarının kullanılması öğrencilerin verilen bir şeklin çevresini hesaplamada izlenilecek yolu öğrendiklerini göstermektedir.

Birinci soruda öğrenciler sırasıyla formül kullanma (\%54.78), zihinden işlem yapma (\%38.86) ve kenar uzunluklarını toplama (\%6.36) stratejilerini kullanmışlardır. Bu sonuçlar, 4. sınıfta öğrencilerin geometrik şekillerin özelliklerini bildiklerini ve işlem becerilerinin gelişmesiyle daha hızlı bir şekilde soruları çözme eğiliminde olduklarını göstermektedir. Çevre hesaplamada tahmin ve standart olmayan birimlerle ölçümler yapıldıktan sonra standart birimlerle ölçme yapılır. Bunun için öncelikle verilen şeklin bütün kenarlarının toplanması ardından formüller kullanılarak verilen şekillerin çevresi hesaplanır (Çilingir Altıner, 2020). Dolayısıyla öğrencilerin en çok tercih ettiği strateji formül kullanma stratejisi olmuştur. Illkokul programında 1. sınıftan itibaren yer alan "Zihinden toplama, çıkarma, çarpma ve bölme işlemleri yapar." kazanımlarıyla öğrencilerin zihinden işlem becerilerinin gelişimi hedeflenmektedir (MEB, 2018). Öğrenciler çevre hesaplama sorularında zihinden işlem yapma stratejisini kullanarak bu kazanımlara uygun bir davranış ortaya koymuşlardır. Ayrıca 4. sınıfta şekillerin çevre uzunluğunun hesaplanmasında kullanılan bir yöntem olan geometrik şeklin kenar uzunluklarının toplanması yöntemi de öğrenciler tarafından tercih edilen bir strateji olmuştur. Bir diğer yöntem ise kare ve dikdörtgen için (karenin bir kenar uzunluğunun 4 ile çarpılması; dikdörtgenin birer uzun ve kısa kenar uzunluğunun toplamının 2 ile çarpılması) formül kullanma yöntemidir. Her iki yöntem de öğrenciler tarafından tercih edilmiş ancak öğrenciler en fazla formül kullanarak soruları çözme eğilimi göstermişlerdir. Öncelikle burada dikkat edilmesi gereken husus direkt ezbere dayalı çevre hesaplama formüllerinin öğrencilere verilmemesi; öğrencilerin kavramsal öğrenmelerini destekleyici çalışmalar ile öğretimin gerçekleştirilmesidir.

Çevre uzunluğunu hesaplama sorusunda, öğrenciler en fazla işlem hatası (\%41.94), sonra ne yapacağını bilmeme hatası (\%35.48) son olarak eksik işlem hatası (\%22.58) yapmışlardır. Bu sonuçlar, öğrencilerin işlemsel becerilerde aceleci davrandıklarını göstermektedir. Ayrıca çevre hesaplama konusunda bir grup öğrencinin yeterli bilgiye sahip olmadığı için alakasız işlemler yaptığı ya da soruyu yanıtsız bıraktığı görülmektedir. Yine öğrencilerin geometrik şekillerin özelliklerini yeterince öğrenemediği için sadece şekillerin (kare, dikdörtgen) iki kenar uzunluğunu toplayarak çevre uzunluğunun hesaplanacağına ilişkin hataları bulunmaktadır. Dağlı ve Peker (2012) çalışmalarında ortaokul öğrencilerinin çevre hesaplama sorularında eksik işlem, işlem hatası ve soruları yanıtsız bırakma gibi yanlışlar yaptıklarını tespit etmeleri bu çalışmanın sonuçlarını destekler niteliktedir. Tan Şişman ve Aksu (2009) verilen bir karenin çevresini hesaplama sorusunda öğrencilerin yaptıkları hataları şu şekilde sıralamıştır: "Çevre yerine alan formülü kullanma, çevre formülünü " $a+b$ " şeklinde kullanma, çevre uzunluğunu farklı ölçü birimleri kullanarak ifade etme ve dört işlemde hata yapma." Bu hata türleri ile çalışmada ortaya konan hata türlerinin benzerlik göstermesi öğrencilerin aynı hataları ortaokul kademesinde de tekrarladıklarını göstermektedir. 
Çevresinin sayısal değeri belli olan bir şekil çizme sorusunda, öğrenciler en fazla ne yapacağını bilmeme hatasını (\%39.22) yapmışlardır. Daha sonra sırasıyla geometrik şeklin yanlış modellenmesinden kaynaklanan hataları (\%33.33), geometrik şeklin kavramsal olarak edinilememesinden kaynaklanan hataları (\%17.65) ve birimkareler çizme hatasını (\%9.80) yapmışlardır. En fazla yapılan hataya göre, öğrenciler daha önce böyle bir soruyla karşılaşmadıkları için ne yapacaklarını bilememişlerdir. Geometrik şekillerin yanlış modellenmesiyle işlemsel beceri eksikliklerinin olduğu görülmektedir. Ayrıca geometrik şekillerin özelliklerini (kare dört eş kenardan, dikdörtgen iki kısa iki uzun kenardan oluşur) tam olarak öğrenemedikleri ve çevre konusunu alan konusuyla karıştırdıkları da belirlenmiştir. Bu sonuçlardan, öğrencilerden soruları sadece çözmelerinin beklendiği ancak kendilerinin bir geometrik şekil çizmeleri istendiğinde o beceriyi gösteremedikleri anlaşılmaktadır. 7. sınıf öğrencileri kitaplarda ya da sınıf içinde çözmeye alışık oldukları kenar uzunluğu verilen geometrik şekillerin çevre uzunluklarını hesaplamada daha başarılıyken alışkın olmadıkları bir şeklin çevre uzunluğunun hesaplanmasında, aynı başarıyı gösterememeleri bu çalışmanın sonuçlarını desteklemektedir (Tan Şişman ve Aksu, 2009). illk soruda olduğu gibi bu soruda da öğrenciler ne yapacaklarını bilememişler, soruya bir cevap verme isteğiyle alakasız geometrik şekiller çizmeyi denemişlerdir. Ayrıca alanyazında geometrik şekillerin özelliklerinin tam olarak öğrenilememesinin öğrencilerin hatalar yapmasına neden olduğunun belirtilmiş olması bu çalışmanın sonuçlarıyla paralellik göstermektedir (Kesici, 2005). Bunun yanında çevre konusunu alan konusuyla karıştıran öğrencilerin yaptığı birimkareler çizme hatası kavramsal olarak bu iki kavramın tam olarak öğrenilemediğini göstermektedir ve ilgili alanyazındaki benzer çalışmalar bu sonucu desteklemektedir (Dağlı ve Peker, 2012; Outhred ve Mitchelmore, 2000; Tan Şişman ve Aksu, 2009). Bu tip yapılan hataların azaltılmasında örneğin, noktalı kâğıt üzerine çizilen kare ve dikdörtgenin kenar uzunlukları kâğıdın başka bir bölgesinde uç uca eklenecek şekilde taşınarak bu şekillerin çevre uzunluklarının hesaplanması gösterilebilir (Güner ve Uygun, 2019). Ayrıca öğrencilerin kendilerinin bu kenar uzunluklarını kullanarak farklı şekiller oluşturmalarına yönelik etkinlikler de yapılabilir.

Çevre hesaplama yöntemini açıklama sorusunda, öğrenciler nasıl tanımlayacağını bilmeme hatasını (\%76.20) ve alan formülü kullanma hatasını (\%23.80) yapmışlardır. Bu sonuçlara göre, öğrencilerin matematiksel bir durumu sözel olarak ifade etmede zorlandıkları ve nasıl cevap vereceklerini bilemedikleri için alan formülü kullanma yolunu tercih ettikleri anlaşılmaktadır. Alanyazında da çevre hesaplama sorularında alan formüllerinin kullanıldığını ortaya koyan çalışmalar bulunmaktadır (Emekli, 2001; Moreira ve Contente, 1997). Öğrencilere geometrik şekillerin çevrelerinin nasıl hesaplanacağını öğretmeden önce çevre kavramının ne olduğu tam olarak açıklanmalıdır. Çevre kavramı öğrenciler tarafından içselleştirildikten sonra çevre formüllerinin kullanımına geçilmelidir. Özellikle bu formüller öğrencilere doğrudan verilmemeli, öğrencilerin bu formülleri geometrik şekillerin (kare, dikdörtgen vb.) özelliklerinden faydalanarak kendilerinin bulması sağlanmalıdır (Baykul, 2014; Güner ve Uygun, 2019). Öğrenciler ilk olarak formülle tanıştıkları zaman kavramsal öğrenmeden ziyade işlemsel öğrenmeye odaklanmakta ve bu tip hatalar meydana gelmektedir. Kavramsal olarak çevre uzunluğunun ne olduğunu kavratabilmek için bir şeklin çevresi önce bir ip yardımıyla dış sınırlarını kapsayacak şekilde ölçülmeli ve bu uzunluk cetvel yardımıyla belirlenmelidir. Ardından yine bu şeklin çevresini oluşturan kenarları cetvelle tek tek ölçüp kenar uzunlukları toplanmalıdır. Her iki durumda da elde edilen sonuçların aynı olduğunu öğrenciler görebilmelidir. Öğrencilerin günlük hayatta kullandıkları nesnelerin dış sınırlarını uygun ölçme araçlarıyla ölçmesi ve sonuçları arkadaşlarıyla paylaşması sağlanmalıdır (Güner ve Uygun, 2019). Bu şekilde ezbere kavramsal öğrenmeyi desteklemeyen bir çalışma yerine öğrencilerin yaptıkları çalışmaları ifade edebildikleri bir çalışma ortaya konmuş olacaktır. Çevre hesaplama konusunda kavramsal öğrenmeyi sağlamış olan öğrencilerin de yaptıkları çalışmayı sözel olarak ifade edebilmeleri kolaylaşacaktır. 
Alan hesaplama, alanı belli olan bir şekil çizme ve alan hesaplama yöntemini açıklama sorularında öğrencilerin büyük bir kısmının şekillerin alanlarının bu alanı kaplayan birimkarelerden oluştuğu bilgisine sahip olduğu sonucuna ulaşılmıştır. Ayrıca öğrenciler alanı belli olan bir şekil çizme sorusunda diğer sorulara göre daha başarılı olmuşlardır. Bunun sebebi olarak öğrencilere şekil çizmeleri için birimkarelerden oluşan bir alanın verilmiş olmasıdır. Verilen alan sayesinde öğrenciler bu soruda ne yapacaklarını anlayarak kolaylıkla görevi yerine getirebilmişlerdir. Tan Şişman ve Aksu (2009) verilen bir dikdörtgenin alanını hesaplama sorusunda öğrencilerin büyük bir çoğunluğunun (\%64.9) başarılı olduklarını belirlemiş olması bu çalışmanın sonuçlarıyla paralellik göstermektedir. Alan hesaplama sorularında birim kavramının önemine vurgu yapan çalışmaların (Barrett vd., 2011; Curry vd., 2006) aksine; 4. sınıftan 9. sınıfa kadar öğrencilerin birimkareyi alan birimi olarak kabul etmediği belirlenmiştir (Olkun vd., 2014). Ancak öğrencilerin verilen şekillerin alanlarını hesaplamada birimkarelerle işlem yapması onların çevre hesaplama sorularındaki başarıları kadar olmasa da alan hesaplama konusunda başarılı olduklarını göstermektedir. 3. sınıfta nesnelerin alanlarının standart olmayan birimlerle kaplanması, 4. sınıfta şekillerinin alanlarının hesaplanmasında birimkarelerin kullanılması; kare ve dikdörtgenin alanını hesaplarken çarpma ve toplama işlemlerinin kullanılarak sonuca ulaşılması öğrencilerin alan hesaplama konusunu öğrendiklerini göstermektedir. Ancak burada dikkat edilmesi gereken husus sınıf içi tartışmalarda öğrencilerin yaptıkları ölçmenin kendileri için ne anlama geldiğini açıklamalarına fırsat vermek olmalıdır (Stephan ve Clements, 2003).

Dördüncü soruda öğrenciler sırasıyla birimkareleri sayma (\%73.11), zihinden işlem yapma (\%21.85) ve bütün parça ile taralı parça ilişkisini ele alma (\%5.04) stratejilerini kullanmışlardır. Bu sonuçlar, 4. sınıfta öğrencilerin geometrik şekillerin alanını hesaplarken birimkareleri tek tek sayarak sonuca ulaşma eğiliminde olduklarını göstermektedir. Gürefe (2018) 8. sınıf öğrencilerinin alan ölçüm problemlerinin çözümünde üçgen ve dikdörtgenle ilgili problemlerde formül kullanma, eşkenar dörtgen ve yamukta çok adımlı stratejileri (parçalama-çıkarma-ekleme-tamamlama, parçalamaformül kullanma vb.) kullanma eğiliminde olduklarını belirlemiştir. Aynı zamanda bütün şekillerin çözümlerinde de sayma stratejisinin kullanıldı̆̆ı belirlenmiştir. Gürefe'nin (2018) yaptığı araştırmadaki sonuçlar ile bu araştırmanın sonuçları örtüşmektedir. İlkokul düzeyinde birimkareler üzerinde verilen şekillerin alanlarının hesaplanmasında öğrenciler renkli birimkareleri sayarak ilkokul 4. sınıf alan ölçme kazanımlarından biri olan "Şekillerin alanlarının, bu alanı kaplayan birimkarelerin sayısı olduğunu belirler." kazanımına uygun bir davranış ortaya koymuşlardır (MEB, 2018). Ancak bu durumun aksine öğrencilerin birimkareyi alan ölçme birimi olarak kullanmadıklarını ortaya koyan çalışmalar da mevcuttur (Kamii ve Kysh, 2006; Olkun vd., 2014). Daha sonra öğrencilerin yine birimkareleri sayarak ya da formül kullanarak sadece sonucu yazmış olmaları onların zihinden işlem yapma stratejisini tercih ettiklerini göstermektedir. Olkun vd. (2014) öğrenciler tarafından tercih edilen en yaygın alan bulma yöntemini, şeklin uzunluğu ile genişliğinin çarpılması yöntemi olarak belirlemişlerdir. Bu sonuç öğrenciler tarafından sadece dört işlem becerilerine dayalı soruların tercih edildiğini; dolayısıyla düşünmeyi gerektirmeyen anlamlı öğrenme alışkanlığından öğrencilerin uzak olduğunu göstermektedir. Bütün parça ile taralı parça arasındaki ilişkiye göre işlem yapmış olan bir grup öğrencinin olması da Gürefe'nin (2018) çok adımlı stratejilerindeki gibi parçalama-çıkarmatamamlama işlemlerine benzer bir sürecin öğrenciler tarafından tercih edildiğini göstermektedir. Çok adımlı stratejiler, verilen şekillerin alan ölçüsünün hesaplanmasında o şekillere ait formüllerin bilinmemesi nedeniyle öğrenciler tarafından tercih edilmektedir. Verilen şekiller üçgen, kare veya dikdörtgene ayrılarak elde edilen şekillerin özelliklerini ya da formüllerini kullanarak alan ölçüleri hesaplanmaktadır (Gürefe, 2018). Elde edilen bu sonuçlara göre, farklı stratejilerin öğrenciler tarafından tercih edilmesi öğrencilerin bireysel hızlarına bağlı tercihlerde bulunduklarını göstermektedir. 
Verilen şekillerin alanlarını bulma sorusunda, öğrenciler en fazla işlem hatasını (\%61.82), sonra ne yapacağını bilmeme hatasını (\%25.45) son olarak çevre uzunluğunu hesaplama hatasını (\%12.73) yapmışlardır. Bu sonuçlara göre, öğrenciler şekillerde yer alan yarım kareleri sayarken dikkatsiz davrandıkları için işlem hatasına düşmüşlerdir. Birimkareler sayılırken sayma stratejisinin çok fazla işlem gerektirmesi öğrencilerin basit şekilde işlemsel hatalar yapmasına sebep olmaktadır. Dolayısıyla alanyazındaki araştırmalar ile bu sonuç paralellik göstermektedir (Gürefe, 2018; Tan Şişman ve Aksu, 2009; Torbeyns, Verschaffel ve Ghesquiere, 2004). Ayrıca bir grup öğrencinin alan hesaplama konusunu öğrenemediği için bu soruyu yanıtsız bıraktığı ya da alakasız cevaplar verdiği görülmektedir. Bunun yanında bir grup öğrenci de çevre hesaplama konusuyla alan hesaplama konusunu karıştırmıştır. Tan Şişman ve Aksu (2009) çalışmalarında öğrencilerin alanı bulmak için şeklin dışını çevreleyen çizgileri saydıklarını tespit etmiş olması bu çalışmanın sonuçlarını desteklemektedir. Çevre hesaplanırken birimkareleri saymak veya alan hesaplanırken şekli çevreleyen çizgileri saymak öğrencilerin bu iki kavramı birbirine karıştırdıklarını göstermektedir (Gürefe, 2018; Olkun vd., 2014; Tan Şişman ve Aksu, 2009). Alanyazında da bu yanılgıların 12 yaşına kadar devam ettiği belirlenmiştir (D’Amore ve Fandiño Pinilla, 2006).

Alanı birimkare cinsinden belli olan bir şekil çizme sorusunda, öğrenciler en fazla geometrik şeklin yanlış modellenmesinden kaynaklanan hataları (\%52.17) yapmışlardır. En az yapılan hata ise ne yapacağını bilmeme hatasıdır (\%47.83). Bu sonuçlara göre, öğrencilerin doğru modeller yapma konusunda işlemsel beceri eksiklikleri bulunmaktadır. Bu hataların aşılmasında hızlı ve bol alıştırma yapmak yerine dinamik geometri yazılımlarıyla geometrik şekillerin özellikleri, formüllerin doğrudan kullanılamayacağı problem çözme etkinlikleriyle geometrik cisimlerin ve kavramların birbirleriyle olan ilişkileri derinlemesine çalışılmalıdır (Olkun vd., 2014). Bununla birlikte bir grup öğrenci bu soruya cevap vermeyerek ne yapacaklarını kestirememişlerdir. Dolayısıyla her zamanki alışık oldukları çözüm alışkanlıkları dışında bir soruyla karşılaşmaları onların hata yapmasına sebep olmuştur. Tan Şişman ve Aksu (2009) alan formülü gerektiren iki kenar uzunluğu verilmiş dikdörtgenin alanını öğrencilerin rahatlıkla hesaplamasına rağmen, verilen bir dikdörtgensel bölgede taralı olmayan alanı bulma konusunda öğrencilerin aynı başarıyı gösteremediklerini belirlemişlerdir. Dolayısıyla işlemsel becerilerde gösterilen başarının kavramsal düzeyde gösterilememesi öğrencilerin alanı belli olan bir şekil çizememelerine neden olmaktadır. Bunun sebebi olarak öğretmenlerin alan öğretiminde uzunluk $x$ genişlik formülünü kullanma eğiliminde olmaları ve öğrencilerin bu formülleri ezberlemek zorunda kalmaları gösterilmektedir (Kidman ve Cooper, 1997; Olkun vd., 2014; Stephan ve Clements, 2003; Zacharos, 2006). Alanın hesaplanmasında örneğin, dikdörtgenin alanı satır ve sütun arasındaki ilişkinin (satırın sütun kere veya sütunun satır kere tekrarlanması) kullanılmasıyla hesaplanabilir. Bu ilişkinin anlaşılmasıyla çevre ve alan formüllerinde yaşanılan karışıkıkların önüne geçilerek alanın kavramsal olarak ne anlama geldiği görülebilir (Güner ve Uygun, 2019).

Alan hesaplama yöntemini açıklama sorusunda, öğrenciler nasıl tanımlayacağını bilmeme hatasını (\%78.43) ve çevre formülü kullanma hatasını (\%21.57) yapmışlardır. Bu sonuçlar, öğrencilerin böyle bir soru tipiyle daha önce karşılaşmadıklarını göstermektedir. Dolayısıyla öğrenciler matematiksel bir durumu sözel olarak ifade etmede zorlanmışlardır. Ayrıca çevre hesaplama konusuyla alan hesaplama konusu öğrenciler arasında karıştırılan bir konu olma özelliğini de devam ettirmektedir. 4, 6 ve 8. sınıf öğrencileriyle yapılan araştırmada öğrencilerin yaklaşık \%50'sinin dikdörtgenin alanını hesaplarken çevre hesaplama yöntemlerini kullanması bu araştırmanın sonuçlarıyla paralellik göstermektedir (Kidman ve Cooper, 1997). Öğrencilerin alan konusunda yaşadıkları güçlüklerin sebepleri arasında öğretmenlerin dersi alan formülü kullanarak (alan=en $\mathrm{x}$ boy) yapılandırmaları gösterilmektedir (Kidman ve Cooper, 1997; Olkun vd., 2014; Stephan ve Clements, 2003; Zacharos, 2006). Yine öğretmen adaylarının öğrencilerin çevre ve alan konularında sahip olduğu farklı kavramalarından haberdar olmamaları bu hataların yapılmasına neden olmaktadır (Runnalls ve Hong, 2017; Şimşek ve Boz, 2015). Bu tür hataların en aza indirilmesinde öğretmenler öncelikle öğrencileri farklı birimlerle ölçüm yapmaya cesaretlendirmeli ve çok yönlü ölçüm 
durumlarıyla karşılaştırmalıdır. Örneğin, bir tangram etkinliği ile öğrencilerin çevrenin şeklin kenar uzunluklarının toplamı olduğu, alanın şeklin kenarlarının çevrelediği bölge olduğu ve çevre değişirken alanın değişmek zorunda olmadığı anlatılabilir (Güner ve Uygun, 2019; Hacıömeroğlu ve Apaydın, 2009). Bu tip çalışmalarla formüllere dayalı alan ölçüm uygulamalarının yerine kavramsal yaklaşım desteklenmiş olacaktır (Stephan ve Clements, 2003; Zacharos, 2006). Ayrıca öğretmen adaylarııın çevre ve alan konularında pedagojik alan bilgilerini arttırmaya yönelik çalışmalara da yer verilmelidir (Runnalls ve Hong, 2017; Şimşek ve Boz, 2015).

Araştırmadan elde edilen sonuçlara göre aşağıdaki önerilerde bulunulabilir:

- Öğrencilerin çevre ve alan hesaplamalarında farklı stratejiler kullanmaları teşvik edilmeli ve kendilerine en uygun çözüm stratejisini seçmeleri desteklenmelidir.

- Ezbere dayalı çevre ve alan hesaplama formülleri öğrencilere doğrudan verilmemeli; öğrencilerin kavramsal öğrenmelerini destekleyici çalışmalar ile bu formüllere kendilerinin ulaşması sağlanmalıdır.

- Çevre ve alan hesaplamalarında öğrencilerin işlemsel becerilerde aceleci davranmamalarına yönelik önlemler alınmalıdır.

- Öğrencilerin sadece verilen şekillerin çözümlerine yönelik değil, kendilerinin de geometrik şekiller çizmelerine ve bu şekillerin çevre ve alan hesaplamalarını kendilerinin ulaşmalarına yönelik etkinlikler tasarlanmalıdır.

- Öğrencilerin çevre ve alan hesaplamalarında yaptıkları işlemleri matematiksel olarak ifade etmelerine yönelik destekleyici sınıf ortamları hazırlanmalıdır.

\section{Etik Kurul Onayı}

Araştırmada kullanılan veri toplama aracına ait Afyon Kocatepe Üniversitesi Sosyal ve Beşeri Bilimleri Bilimsel Araştırma ve Yayın Etiği Kurulu'nun 18.12.2020 tarih ve 2020/238 sayılı kararı gereği gerekli Etik Kurul onayı alınmıştır. 


\section{Kaynakça}

Akar, H. (2017). Durum çalışması. A. Saban ve A. Ersoy (Ed.). Eğitimde nitel araştırma desenleri (s. 139-177) içinde. Ankara: Anı Yayıncılık.

Barrett, J. E., Cullen, C., Sarama, J., Clements, D. H., Klanderman, D., Miller, A. L. ve Rumsey, C. (2011). Children's unit concepts in measurement: a teaching experiment spanning grades 2 through 5. ZDM Mathematics Education, 43, 637-650. doi: 10.1007/s11858-011-0368-8

Baykul, Y. (2014). Ilkokulda matematik öğretimi (12. bs.). Ankara: Pegem Akademi Yayıncılık.

Biber, A. Ç. (2019). Matematik ve öğretimi. A. Kaçar (Ed.). ilkokulda matematik öğretimi (s. 1-14) içinde. Ankara: Pegem Akademi Yayıncılık.

Bozoğlu, U. (2013). Ortaokul 7. sınıf matematik dersi alan-çevre ilişkisi konusunda oyun temelli öğretimin öğrenci başarısına etkisi. (Yayımlanmamış yüksek lisans tezi). Ondokuz Mayıs Üniversitesi, Eğitim Bilimleri Enstitüsü, Samsun.

Büyüköztürk, Ş., Kılıç Çakmak, E., Akgün, Ö. E., Karadeniz, Ş. ve Demirel, F. (2020). Eğitimde bilimsel araştırma yöntemleri (28. bs.). Ankara: Pegem Akademi Yayıncılık.

Chappell, M. F. ve Thompson, D. R. (1999). Perimeter or area? Which measure is it?. Mathematics Teaching in the Middle School, 5(1), 20-23.

Curry, M., Mitchelmore, M. C. ve Outhred, L. (2006). Development of children's understanding of length, area and volume measurement principles. J. Novotná, H. Moraová, M. Krátká ve N. Stehlíková (Ed.), Proceedings of the 30th annual conference of the PME, 2, 377-384. Prague, Czechia: Program Committee.

Çilingir Altıner, E. (2019). Ölçme. V. Toptaş (Ed.). Illkokulda temel matematik (s. 185-221) içinde. Ankara: Vizetek Yayıncılık.

Çilingir Altıner, E. (2020). Ölçme. V. Toptaş, S. Olkun, S. Çekirdekçi, M. H. Sarı (Ed.). ilkokulda matematik öğretimi (s. 367-423) içinde. Ankara: Vizetek Yayıncılık.

Dağlı, H. ve Peker, M. (2012). İlköğretim 5. sınıf öğrencileri geometrik şekillerin çevre uzunluğunu hesaplamaya ilişkin ne biliyor? Kuramsal Eğitimbilim Dergisi - Journal of Theoretical Educational Science, 5(3), 330351.

D’Amore, B. ve Fandiño Pinilla, M. I. (2006). Relationships between area and perimeter: Beliefs of teachers and students. Mediterranean Journal for Research in Mathematics Education, 5(2), 1-29.

Divrik, R. (2020). illkokul matematik dersi öğretim programı. V. Toptaş, S. Olkun, S. Çekirdekçi, M. H. Sarı (Ed.). ilkokulda matematik öğretimi (s. 93-125) içinde. Ankara: Vizetek Yayıncılık.

Emekli, A. (2001). Ölçüler konusunun öğretiminde yanılgıların teşhisi ve alınması gereken tedbirler. (Yayımlanmamış yüksek lisans tezi). Selçuk Üniversitesi, Fen Bilimleri Enstitüsü, Konya.

Grant, T. J., ve Kline, K. (2003). Developing the building blocks of measurement with young children. D. H. Clements ve G. Bright (Ed.), Learning and Teaching Measurement 2003 Yearbook (s. 46-57) içinde. Reston, VA: NCTM.

Güler Selek, H. K. (2020). Matematik. V. Toptaş, S. Olkun, S. Çekirdekçi, M. H. Sarı (Ed.). Ilkokulda matematik öğretimi (s. 1-15) içinde. Ankara: Vizetek Yayıncılık.

Güner, P. ve Uygun, T. (2019). Temel geometri ve ölçü kavramı öğretimi. A. Kaçar (Ed.). Ilkokulda matematik öğretimi (s. 239-315) içinde. Ankara: Pegem Akademi Yayıncılık.

Gürefe, N. (2018). Ortaokul öğrencilerinin alan ölçüm problemlerinde kullandıkları stratejilerin belirlenmesi. Hacettepe Üniversitesi Eğitim Fakültesi Dergisi, 33(2), 417-438. doi: 10.16986/HUJE.2017032703

Hacı̈meroğlu, G. ve Apaydın, S. (2009). Tangram etkinliği ile çevre ve alan hesabı. ilköğretim Online, 8(2), 1-6.

Kamii, C. ve Kysh, J. (2006). The difficulty of "length $x$ width": Is a square the unit of measurement?. Journal of Mathematical Behavior, 25, 105-115.

Kesici, A. (2005). Lise öğrencilerinin geometri-1 dersinde geçen bazı kavramları öğrenme düzeyleri üzerine bir araştırma. (Yayımlanmamış yüksek lisans tezi). Yüzüncü Yıl Üniversitesi, Fen Bilimleri Enstitüsü, Van.

Kidman, G. ve Cooper, T. J. (1997). Area integration rules for grades 4, 6, 8 students. E. Pehkonen (Ed.), Proceedings of the 21st Annual Conference of the International Group for the Psychology of Mathematics Education, 3, 132-143. Lahti, Finland: University of Finland.

Kültür, M. N., Kaplan, A. ve Kaplan, N. (2002). İlköğretim okulları 4. ve 5. sınıflarda uzunluk, alan ve hacim ölçüleri konularının öğretiminin değerlendirilmesi. Kastamonu Eğitim Dergisi, 10(2), 297-308.

Millî Eğitim Bakanlığı [MEB] (2018, Temmuz). Matematik dersi öğretim programı (ilkokul ve ortaokul 1, 2, 3, 4, 5, 6, 7 ve 8. sınıflar). Erişim Adresi (11.07.2020): http://ttkb.meb.gov.tr/ 
Millî Eğitim Bakanlığı [MEB] (2020, Aralık). TIMSS 2019 Türkiye ön raporu. Erişim Adresi (25.12.2020): https://odsgm.meb.gov.tr/meb_iys_dosyalar/2020_12/10175514_TIMSS_2019_Turkiye_On_Raporu_. pdf

Miles, M. B. ve Huberman, A. M. (1994). Qualitative data analysis: An expanded source book (2. bs.). Thousand Oaks, CA: Sage.

Moreira, C. Q. ve Contente, M. do R. (1997). The role of writing to foster pupil's learning about area. E. Pehkonen (Ed.), Proceedings of the 21st PME International Conference, 3, 256-263. Lahti, Finland: University of Helsinki, Lahti Research and Training Centre.

National Council of Teachers of Mathematics [NCTM] (2000). Principles and standarts for school mathematics. Reston, VA: National Council of Teachers of Mathematics Publishing.

Olkun, S., Çelebi, Ö., Fidan, E., Engin, Ö. ve Gökgün, C. (2014). The meaning of unit square and area formula for Turkish students [in Turkish]. Hacettepe Üniversitesi Eğitim Fakültesi Dergisi [Hacettepe University Journal of Education], 29(1), 180-195.

Olkun, S. ve Toptaş, V. (2019). Ilkokullar için resimli matematik terimleri sözlüğü (3. bs.). Ankara: Vizetek Yayıncılık.

Olkun, S. ve Toluk Uçar, Z. (2020). Ilköğretimde etkinlik temelli matematik öğretimi (9. bs). Ankara: Vizetek Yayıncılık.

Outhred, Lynne N. ve Mitchelmore, Michael C. (2000). Young children's intuitive understanding of rectangular area measurement. Journal for Research in Mathematics Education, 31(2), 144-167.

Özçelik, U. (2018). Ilkokul matematik 4 ders kitabı. Ankara: Ata Yayıncılık.

Pesen. C. (2020). Ilkokullarda matematik öğretimi (1-4. sınıflar) (8. bs). Ankara: Pegem Akademi Yayıncılık.

Runnalls, C. ve Hong, D. S. (2017). Well, they understand the concept of area: Pre-service teachers' responses to student area misconceptions. Galindo, E., ve Newton, J., (Ed.). Proceedings of the 39th annual meeting of the North American Chapter of the International Group for the Psychology of Mathematics Education (s. 881-884) içinde. Indianapolis, IN: Hoosier Association of Mathematics Teacher Educators.

Stephan M. ve Clements. D. H. (2003). Linear and area measurement in prekindergarten to grade 2. D. H. Clements ve G. Bright (Ed.), Learning and Teaching Measurement 2003 Yearbook (s. 3-16) içinde. Reston, VA: NCTM.

Şimşek, N. ve Boz, N. (2015). Sınıf öğretmeni adaylarının uzunluk ölçme konusunda pedagojik alan bilgilerinin öğrenci kavrayışları bağlamında incelenmesi. Cumhuriyet International Journal of Education-CIJE, 4(3), 10-30.

Tan Şişman, G. ve Aksu, M. (2009). Yedinci sınıf öğrencilerinin alan ve çevre konularındaki başarıları. ilköğretim Online, 8(1), 243-253.

Tan Şişman, G., ve Aksu, M. (2015). A study on sixth grade students' misconceptions and errors in spatial measurement: Length, area, and volume. International Journal of Science and Mathematics Education, 14(7), 1293-1319. doi: 10.1007/s10763-015-9642-5

Torbeyns, J., Verschaffel, L., ve Ghesquiere, P. (2004). Strategic aspects of simple addition and subtraction: The influence of mathematical ability. Learning and Instruction, 14, 177-195.

Yıldırım, A. ve Şimşek, H. (2006). Sosyal bilimlerde nitel araştırma yöntemleri (6. bs). Ankara: Seçkin Yayıncılık.

Yıldırım Yakar, Z., ve Albayrak, M. (2018). The effect of the layered curriculum method on the students' achievement in "area measurement". Hacettepe University Journal of Education, 34(2), 565-585. doi: 10.16986/HUJE.2018044393

Yin, R.K. (2014). Case study methods: Design and methods (5. bs). Thousand Oaks: Sage Pbc.

Zacharos, K. (2006). Prevailing educational practices for area measurement and students' failure in measuring areas. Journal of Mathematical Behavior, 25, 224-239. doi: 10.1016/j.jmathb.2006.09.003

Zembat, í. Ö. (2009). Ölçme temel bileşenleri ve sık karşılaşılan kavram yanılgıları. Bingölbali, E. ve Özmantar, M. F (Ed.). ilköğretimde karşılaşılan matematiksel zorluklar ve çözüm önerileri (s. 127-154) içinde. Ankara: Pegem Akademi Yayıncılık. 